\title{
Hyperlipidemic Rabbit Models for Anti-Atherosclerotic Drug Development
}

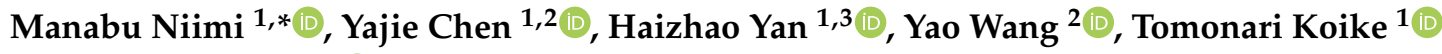 \\ and Jianglin Fan 1,2,*(D) \\ 1 Department of Molecular Pathology, Graduate School of Medicine, University of Yamanashi, Chuo, \\ Yamanashi 409-3898, Japan; lywchen@163.com (Y.C.); yanhaizhao@126.com (H.Y.); \\ koike512@outlook.jp (T.K.) \\ 2 School of Biotechnology and Health Sciences, Wuyi University, Jiangmen, Guangdong 529020, China; \\ wangyao_1125@hotmail.com \\ 3 Key Laboratory of Regenerative Biology, South China Institute for Stem Cell, \\ Biology and Regenerative Medicine, Guangzhou Institutes of Biomedicine and Health, \\ Chinese Academy of Sciences, Guangzhou 510530, China \\ * Correspondence: manabun@yamanashi.ac.jp (M.N.); jianglin@yamanashi.ac.jp (J.F.)
}

Received: 6 November 2020; Accepted: 2 December 2020; Published: 4 December 2020

\begin{abstract}
Hyperlipidemia or dyslipidemia is a major risk factor for atherosclerotic diseases. Experimental animals play an important role in elucidating the molecular mechanisms of the pathophysiology of hyperlipidemia as well as in drug development. Rabbits are one of the most suitable models to study human hyperlipidemia because many features of the lipoprotein metabolism of rabbits are similar to those of humans such as LDL-rich lipoproteins in plasma, apolipoprotein B mRNA editing, and cholesteryl ester transfer protein. Currently, three types of rabbit models are commonly used for studying hyperlipidemia: (1) diet-induced hyperlipidemic rabbits, (2) spontaneous hyperlipidemic rabbits, and (3) gene-manipulated rabbits (transgenic and knockout rabbits). In this review, we give an overview of the features of hyperlipidemic rabbits and discuss the usefulness of rabbits for the development of anti-atherogenic drugs.
\end{abstract}

Keywords: rabbit; hyperlipidemia; lipoprotein; apolipoprotein; drug development

\section{Introduction}

Hyperlipidemia is one of the major risk factors for atherosclerosis, which has been the leading cause of mortality globally [1,2]. It is generally believed that an increase in plasma low-density lipoprotein (LDL), triglycerides (TG)-rich lipoproteins such as chylomicron (CM), and very-low-density lipoprotein (VLDL) and/or a decrease in high-density lipoprotein (HDL) are associated with or cause atherosclerosis [3]. For the study of human lipid disorders as well as for the development of therapeutic agents, it is essential to use an appropriate experimental animal. Ideal animal models for human hyperlipidemia should possess several important characteristics: (1) they should be easy to induce hyperlipidemia by diet intervention or genetic manipulation, (2) they should have similar lipoprotein profiles as humans, (3) they should be easy to handle and be of the proper size to allow for all anticipated experimental manipulations, and (4) they should be easy to acquire and maintain at a reasonable cost [4]. Until now, many animal models have been used for the study of hyperlipidemia, including mice, rats, hamsters, guinea pigs, rabbits, pigs, and nonhuman primates. Unfortunately, there is no single animal model that fulfills all the requirements. Although each animal model has its advantages and limitations with respect to plasma lipoprotein profiles, handling, reproducibility, and cost, rabbits possess several unique advantages for the study of lipid metabolism. Due to their high 
susceptibility to a cholesterol diet, it is easy to induce hyperlipidemia and atherosclerosis in wild-type rabbits [5], which is different from most strains of wild-type mice. The hyperlipidemic models of mice have been generated by the targeting of genes, such as apolipoprotein (apo) E and LDL receptor (LDLR) [6,7]. Nevertheless, there are a number of features that make rabbits an appropriate model to study human hyperlipidemia. Unlike wild-type mice and rats (rodents) in which HDL is a major lipoprotein in plasma, $\approx 40 \%$ of plasma cholesterol in wild-type rabbits and $>90 \%$ in cholesterol-fed rabbits are contained in the apo B-containing particles such as VLDL and LDL [8]. Humans and rabbits have abundant plasma cholesteryl ester transfer protein (CETP), an important regulator of HDL and cholesterol metabolism, whereas rodents do not have CETP [9]. Given that the restricted editing of apo B mRNA only occurs in the intestine in humans and rabbits, apo B-48 is only present in intestinally derived $\mathrm{CM}$ and $\mathrm{CM}$ remnants in humans and rabbits. However, in rodents, apo B mRNA editing occurs in both the intestine and liver [10]; therefore, apo B-48 is contained in both CM and VLDL particles. Furthermore, hepatic LDLR in both humans and rabbits is highly down-regulated according to the level of cholesterol uptake in the liver [8]. In addition, the appropriate size of rabbits enables researchers to obtain large amounts of plasma samples for both in vitro and in vivo studies.

\section{Hyperlipidemic Rabbit Models}

\subsection{Diet-Induced Hyperlipidemic Rabbits}

\subsubsection{Cholesterol-Fed Rabbits}

Rabbits are the first models for the study of lipoprotein metabolism and atherosclerosis. In 1913, a Russian experimental pathologist, Anitschow, described that feeding cholesterol dissolved in sunflower oil to rabbits elevated blood cholesterol levels, and within several weeks, rabbit arteries showed atherosclerotic lesions [11]. As herbivores, laboratory rabbits including New Zealand white (NZW) and Japanese white (JW) rabbits, on a normal standard diet, have relatively low plasma total cholesterol (TC) levels (30-90 mg/dL) at the age of 3-4 months compared with humans. When rabbits are fed a cholesterol diet, they rapidly develop hypercholesterolemia [12]. Kolodgie et al. tested low dietary cholesterol $(0.05 \%$ to $0.25 \%)$ with $6 \%$ peanut oil for 30 weeks to explore a response of plasma TC levels in rabbits. Dietary cholesterol in the range of $0.05 \%$ to $0.15 \%$ resulted in a less than 2 -fold stepwise increase in plasma TC, whereas rabbits receiving $0.20 \%$ and $0.25 \%$ dietary cholesterol showed significantly higher (4- to 5-fold) plasma TC compared to those rabbits fed a diet containing $0.05 \%$ to $0.15 \%$ cholesterol [13]. Cholesterol diets contain more than $1 \%$ cholesterol usually causes extraordinary elevation of plasma TC levels in rabbits, exceeding $2000 \mathrm{mg} / \mathrm{dL}$. Such high level of plasma TC is never seen in human hypercholesterolemia. Therefore, it is generally recommended to use a $0.3-0.5 \%$ cholesterol diet, which results in hypercholesterolemia comparable to human familial hypercholesterolemia (FH) [8]. The major elevated lipoproteins in cholesterol-fed rabbits are those lipoproteins (called $\beta$-VLDL) derived from both the intestine and liver and they are quite atherogenic because they are rich in cholesteryl esters and can induce macrophages to transform into foam cells [14].

Currently, we recommend a diet supplemented with $0.3-0.5 \%$ cholesterol and 3\% soybean oil fed either ad libitum or restricted for most rabbit experiments. Representative hypercholesterolemia in cholesterol-fed rabbits is shown in Figure 1A. Plasma TC levels start to rise within one week and remain at high levels $(\approx 800 \mathrm{mg} / \mathrm{dL})$ thereafter. Hyperlipidemic rabbits can develop aortic lesions as early as four-six weeks after cholesterol diet feeding, but at 16 weeks, $20-40 \%$ of the aortic surface is covered by atherosclerosis which can be stained with Sudan IV (Figure 1B). The age of rabbits should be considered because young rabbits are more susceptible to aortic atherosclerosis than old rabbits even though there are no differences in plasma TC levels [15]. 
A

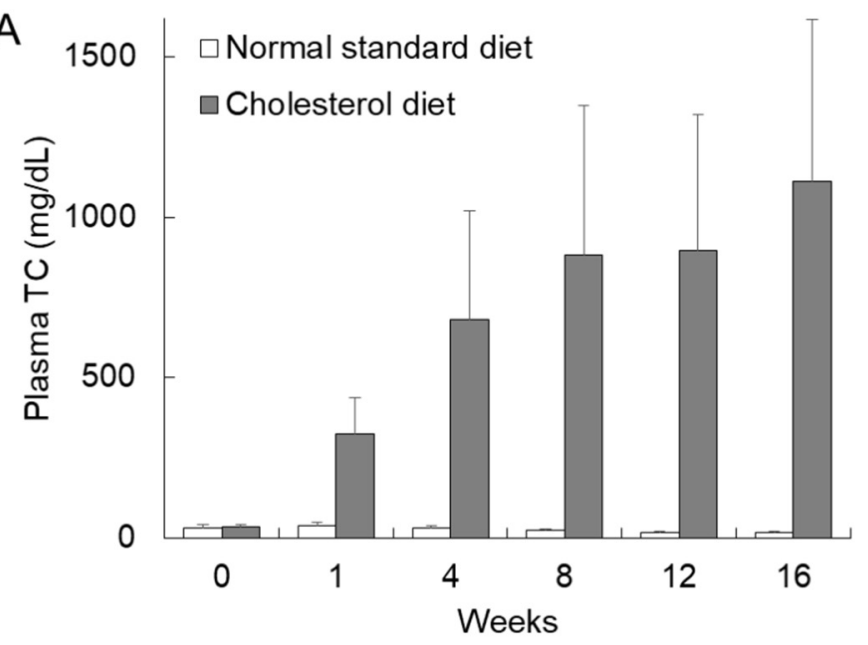

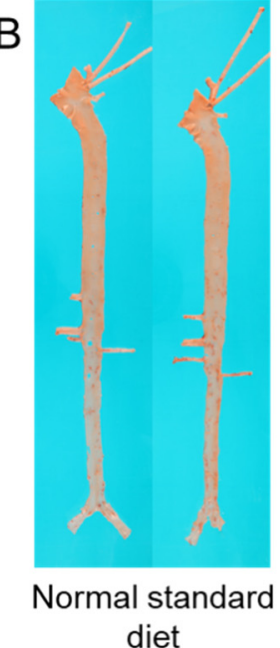

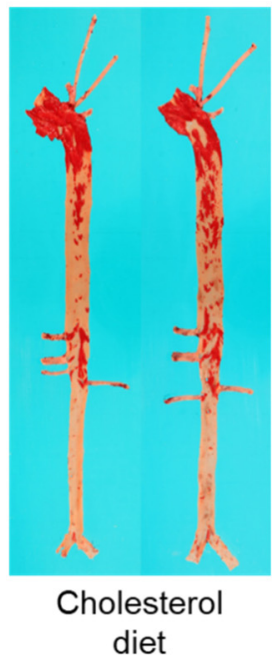

Figure 1. Hypercholesterolemia and representative aortic atherosclerosis of cholesterol-fed rabbits. (A) Plasma total cholesterol (TC) levels of wild-type rabbits fed either a normal standard diet or a cholesterol diet containing $0.3 \%$ cholesterol and 3\% soybean oil for 16 weeks. Mean \pm SD $(n=4-20)$.

(B) Aortic gross lesion stained with Sudan IV can be seen in rabbits fed a cholesterol diet (right).

\subsubsection{Casein-Fed Rabbits}

A cholesterol-free, casein-enriched diet can also induce hypercholesterolemia and atherosclerosis in rabbits. In general, hypercholesterolemia is induced in rabbits by feeding them a semi-purified diet enriched in $27 \%$ casein, and plasma TC levels are increased up to $300-800 \mathrm{mg} / \mathrm{dL}$ and accompanied by aortic atherosclerosis $[16,17]$. This model is seldom used; however, the possible mechanism for hypercholesterolemia is considered as being caused by decreased bile acids synthesis and fecal sterol excretion, which leads to increased hepatic cholesterol, followed by down-regulation of LDLR [18-20]. The major elevated lipoproteins in casein-fed rabbits are LDLs, which is different from $\beta$-VLDLs present in cholesterol-fed rabbits. Daley et al. compared casein-fed rabbits with cholesterol-fed rabbits and found that even though with similar high hypercholesterolemia $(\approx 500 \mathrm{mg} / \mathrm{dL})$, casein-fed rabbits developed significantly less aortic atherosclerosis than cholesterol-fed rabbits [17].

\subsection{Spontaneous Hyperlipidemic Rabbits}

\subsubsection{Watanabe Heritable Hyperlipidemic (WHHL) Rabbits}

The WHHL rabbit was established by Dr. Watanabe in the 1970s at Kobe University in Japan [21,22] and is often used as a model of human familial hypercholesterolemia (FH). FH is an autosomal dominant genetic disorder characterized by elevated plasma LDL levels due to LDLR dysfunctions [23]. WHHL rabbits are genetically deficient in LDLR functions, therefore, even on a normal standard diet, they showed hyperlipidemia (plasma TC, 385-518 mg/dL, and TG, 304-511 mg/dL), being 10-fold and 8 -fold higher than normal wild-type rabbits [22]. Serum lipoproteins characterized by electrophoresis exhibited elevated $\beta$-lipoprotein with a broad $\beta$-pattern and diminished $\alpha$-lipoprotein in WHHL rabbits. Yamamoto et al. demonstrated that WHHL rabbits have a dysfunctional LDLR with an in-frame deletion of 12 nucleotides that eliminate four amino acids from the ligand-binding domain of the LDLR. Mutant LDLRs cannot transport to the cell surface at a normal rate [24]. The dysfunction of the LDLR in WHHL rabbits results in a loss of the hepatic uptake of LDL and subsequent elevation of the plasma LDL levels similar to human FH [25-27]. Age-related changes in plasma lipids were observed in WHHL rabbits [22,28]. Compared with 3-month-old juvenile rabbits, 24-month-old rabbits showed a $45 \%$ decrease in TC (916 at 3 months to $508 \mathrm{mg} / \mathrm{dL}$ at 24 months) and a $42 \%$ decrease in LDL-C (680 at 3 months to $393 \mathrm{mg} / \mathrm{dL}$ at 24 months) [28]. Atkinson et al. compared plasma TC levels in heterozygous WHHL rabbits and NZW rabbits on a cholesterol diet for 24 weeks. On a $0.5 \%$ cholesterol 
diet, plasma TC levels in heterozygous WHHL rabbits were significantly higher than those in NZW rabbits ( $\approx 2000$ in WHHL vs. $\approx 1000 \mathrm{mg} / \mathrm{dL}$ in NZW rabbits). However, on a 1\% cholesterol diet, plasma TC levels reached a peak $(\approx 3000 \mathrm{mg} / \mathrm{dL})$ at eight weeks in both rabbits without significant differences between the two groups [29].

Besides spontaneous hypercholesterolemia and atherosclerosis, WHHL rabbits exhibited other metabolic abnormalities including insulin resistance [30] and visceral fat accumulation [31]. Some WHHL rabbits (also designated as myocardial infarction-prone Watanabe heritable hyperlipidemic, WHHLMI) developed coronary atherosclerosis and myocardial infarction [8,32,33]. To obtain a myocardial infarction-prone colony, WHHL rabbits with severe coronary atherosclerosis, myocardial infarction, and relatively higher plasma TC levels were selected and bred. Selective breeding was carried out for five to seven generations. WHHLMI rabbits exhibit $93 \%$ of coronary stenosis and $97 \%$ of myocardial infarction, whereas the corresponding values are $60 \%$ and $23 \%$ in original WHHL rabbits [32].

\subsubsection{St. Thomas' Mixed Hyperlipidemic (SMHL) Rabbits}

The SMHL rabbit is a putative model of familial combined hyperlipidemia originally described as the St. Thomas' Hospital rabbit in the 1980s. These rabbits showed spontaneously elevated plasma TC levels (394 mg/dL, 4- to 5-fold over normal rabbits) with moderately high or normal plasma TG levels (151 mg/dL, 2-fold over normal rabbits) and developed aortic atherosclerosis on a normal standard diet $[34,35]$. SMHL rabbits have normal LDLR function, and it is considered that elevated plasma VLDL and LDL levels are caused by overproduction of apoB-containing particles from the liver $[34,36]$. De Roos et al. compared plasma lipids of SMHL rabbits with WHHL rabbits on a low-cholesterol diet. With three months of feeding a $0.08 \%$ cholesterol diet, SMHL rabbits showed plasma TC of $264 \pm 68$ and TG of $290 \pm 55 \mathrm{mg} / \mathrm{dL}$ compared with the TC of $791 \pm 36$ and TG of $232 \pm 46 \mathrm{mg} / \mathrm{dL}$ in WHHL rabbits [37].

\subsubsection{Postprandial Hypertriglyceridemic (PHT) Rabbits}

The PHT rabbit was established through cross-breeding between WHHL rabbits with a hypertriglyceridemia phenotype and normal JW rabbits [38,39]. PHT rabbits showed high TG levels in both fasting ( $403 \mathrm{mg} / \mathrm{dL}, 11$-fold over normal rabbits) and postprandial (1407 mg/dL, 22-fold over normal rabbits) states. In addition to hypertriglyceridemia, PHT rabbits exhibited insulin resistance along with obesity [39].

\subsection{Gene-Manipulated Rabbits}

\subsubsection{Transgenic (Tg) Rabbits}

Hyperlipidemic rabbits were also generated by the overexpression of human apo B-100, E, and C-III genes in the liver. Human apo B-100 Tg rabbits resulted in a 3-fold increase in plasma TC and TG levels compared with those in non-Tg rabbits, and the majority of the plasma TC was distributed in the LDL, with striking enrichment of TG content [40]. Ding et al. generated Tg rabbits overexpressing the human apo C-III gene. Apo C-III Tg rabbits showed 3-fold higher plasma TG levels than non-Tg rabbits (191 in Tg vs. $59 \mathrm{mg} / \mathrm{dL}$ in non-Tg), although TC and HDL-C levels were not changed. Lipoprotein analysis revealed that increased TG in apo C-III Tg rabbits was distributed in CM and VLDL [41]. Tg rabbits expressing human apo E3, the most common isoform in humans, and apo E2, a variant associated with type III hyperlipoproteinemia, were also reported. Tg rabbits expressing higher levels of human apo E3 (>20 mg/dL) showed marked combined hyperlipidemia characterized by an increase in both LDL and VLDL [42,43]. Overexpression of human apo E2 in rabbits exhibited 8 -fold increases in plasma TC and 15-fold increases in plasma TG compared with non-Tg rabbits [44]. 


\subsubsection{Knockout (KO) Rabbits}

For a long time, it had been impossible to generate KO rabbits; however, the emergence of recent gene-editing technologies has dramatically changed the field of $\mathrm{KO}$ rabbits. Recently, apo $\mathrm{E}$ and LDLR KO rabbits were generated and have been used for the study of hyperlipidemia [45-47]. ApoE-KO rabbits exhibited mild hyperlipidemia, with TC levels at $\approx 200 \mathrm{mg} / \mathrm{dL}$, on a normal standard diet $[46,48]$. When challenged with a cholesterol diet, apo E KO rabbits showed greater susceptibility to hyperlipidemia than did the wild-type rabbits, and their plasma TC and TG levels were remarkably increased, with a 6.3-fold increase in TC and a 5.7-fold increase in TG compared with those of wild-type rabbits [48]. Hyperlipidemia in apo E KO rabbits was caused by elevated remnant lipoproteins predominated by apo B-48 and rich in both apo A-I and apo A-IV contents. Lu et al. generated LDLR KO rabbits and found that, similar to WHHL rabbits, LDLR deficiency markedly increased plasma TC levels (272-1013 in LDLR-KO rabbits vs. $51 \mathrm{mg} / \mathrm{dL}$ in the wild-type rabbits) on a normal standard diet. Increased plasma TC levels were mainly caused by elevated LDL-C (124-730 in LDLR-KO rabbits vs. $21 \mathrm{mg} / \mathrm{dL}$ in the wild-type rabbits) [47]. Apo E and LDLR double-KO rabbits were also generated by the same group and exhibited remarkable hyperlipidemia on a normal standard diet [49]. These KO rabbits may be useful for anti-atherosclerotic drug development in the future.

\section{Hyperlipidemic Rabbit Models for the Development of Drugs}

As mentioned above, rabbits are also useful in the research of lipid-lowering drugs due to their similarity with human lipid metabolism. In this respect, the most important contribution made by hypercholesterolemic rabbits is the discovery of a potent lipid-lowering drug, statin, the best prescribed drug for hyperlipidemic patients in the world [50]. In the 1970s, Endo discovered the first statin, named compactin (also called ML-236B or mevastatin) [51]. However, at first, he found that compactin could not reduce plasma cholesterol in mice and rats [52], so his company almost terminated the study. Later, Endo continued to conduct his research using different animals such as rabbits, monkeys, and dogs and finally disclosed that compactin indeed exhibited lipid-lowering effects [53-56]. Now, we know that rodents are basically different from humans and rabbits in terms of cholesterol metabolism, and the majority of cholesterol in rodents is derived from food, whereas in humans and rabbits, cholesterol is mainly synthesized in the liver [8]. Therefore, using hypercholesterolemic rabbits, one can not only test a new drug but can also examine new functions of existing drugs.

\subsection{Statins}

Statins, 3-hydroxy-3-methyl-glutaryl-CoA (HMG-CoA) reductase inhibitors, have been widely used by hyperlipidemic patients. Statins have a similar structure to HMG-CoA, a precursor of cholesterol, and inhibit HMG-CoA reductase, the rate-limiting enzyme of cholesterol biosynthesis, which is the major pathway for its lipid-lowering functions [57]. In addition, statins indirectly up-regulate LDLR activity and reduce the secretion of VLDL into circulation [57]. The lipid-lowering and atheroprotective effects of statins have been verified by many studies using different hypercholesterolemic rabbits (Table 1).

Regardless of different types of statins, doses, and durations, all studies showed that statins can reduce plasma TC levels in hypercholesterolemic rabbits, while some studies failed to demonstrate anti-atherogenic effects. Bocan et al. reported that atorvastatin showed anti-atherogenic effects in an iliac-femoral artery microscopic lesion but did not reach a significant difference in the thoracic aorta gross lesion [58]. Pravastatin significantly reduced plasma TC levels and coronary atherosclerotic lesions in WHHL rabbits but had no effects on aortic atherosclerotic lesions [59]. These studies indicate that the efficacy of statins on atherosclerosis is more complicated than their lipid-lowering effect, possibly due to the pluripotent effect of statins. 
Table 1. Lipid-lowering and anti-atherosclerotic effects of statins in rabbit models.

\begin{tabular}{|c|c|c|c|c|c|}
\hline Rabbit & Diet & Drug & Plasma TC & Atherosclerosis & Reference \\
\hline \multicolumn{6}{|c|}{ Wild-type rabbits } \\
\hline $\begin{array}{c}\text { JW } \\
\text { (Female) }\end{array}$ & $\begin{array}{l}\text { Normal } \\
\text { standard }\end{array}$ & $\begin{array}{l}\text { Compactin }(5 \mathrm{mg} / \mathrm{kg}) \\
\text { Compactin }(25 \mathrm{mg} / \mathrm{kg}) \\
\text { for } 2 \text { weeks }\end{array}$ & $\begin{array}{c}16 \% \downarrow \\
41 \% \downarrow \\
\text { (2 weeks) }\end{array}$ & - & $\begin{array}{l}\text { Watanabe } \\
\text { [54] }\end{array}$ \\
\hline $\begin{array}{l}\text { NZW } \\
\text { (Male) }\end{array}$ & $\begin{array}{l}27 \% \text { casein } \\
\text { semi-purified }\end{array}$ & $\begin{array}{l}\text { Lovastatin }(2 \mathrm{mg} / \mathrm{kg}) \\
\text { Lovastatin }(6 \mathrm{mg} / \mathrm{kg}) \\
\text { for } 39 \text { days }\end{array}$ & $\begin{array}{c}37 \% \downarrow^{*} \\
48 \% \downarrow^{*} \\
\text { (39 days) }\end{array}$ & - & Kroon [60] \\
\hline $\begin{array}{l}\text { NZW } \\
\text { (Male) }\end{array}$ & $\begin{array}{c}2 \% \text { cholesterol } \\
6 \% \text { corn oil }\end{array}$ & $\begin{array}{l}\text { Lovastatin }(2.5 \mathrm{mg} / \mathrm{kg}) \\
\text { for } 8 \text { weeks }\end{array}$ & $\begin{array}{c}54 \% \downarrow^{*} \\
\text { (8 weeks) }\end{array}$ & $\begin{array}{c}43 \% \downarrow^{*} \\
\text { (Aortic arch, scale graded } \\
\text { gross lesion) }\end{array}$ & $\begin{array}{c}\text { Kritchevsky } \\
{[61]}\end{array}$ \\
\hline $\begin{array}{l}\text { JW } \\
\text { (Male) }\end{array}$ & $1 \%$ cholesterol & $\begin{array}{c}\text { Lovastatin }(5 \mathrm{mg} / \mathrm{kg}) \\
\text { Simvastatin }(5 \mathrm{mg} / \mathrm{kg}) \\
\text { for } 12 \text { weeks }\end{array}$ & $\begin{array}{c}50 \% \downarrow^{*} \\
80 \% \downarrow^{*} \\
\text { (12 weeks) }\end{array}$ & $\begin{array}{c}74 \% \downarrow^{*} \\
81 \% \downarrow^{*} \\
\text { (Aorta, gross lesion) }\end{array}$ & $\begin{array}{c}\text { Kobayashi } \\
\text { [62] }\end{array}$ \\
\hline $\begin{array}{l}\text { NZW } \\
\text { (Male) }\end{array}$ & $\begin{array}{l}27 \% \text { casein } \\
\text { semi-purified }\end{array}$ & $\begin{array}{l}\text { Lovastatin }(3 \mathrm{mg} / \mathrm{kg}) \\
\text { Atorvastatin }(3 \mathrm{mg} / \mathrm{kg}) \\
\text { for } 6 \text { weeks }\end{array}$ & $\begin{array}{c}20 \% \downarrow^{*} \\
57 \% \downarrow^{*} \\
\text { (6 weeks) }\end{array}$ & - & $\begin{array}{l}\text { Auerbach } \\
\text { [63] }\end{array}$ \\
\hline $\begin{array}{l}\text { NZW } \\
\text { (Male) }\end{array}$ & $\begin{array}{c}0.5 \% \\
\text { cholesterol } \\
3 \% \text { peanut oil } \\
3 \% \text { coconut oil }\end{array}$ & $\begin{array}{c}\text { Lovastain }(2.5 \mathrm{mg} / \mathrm{kg}) \\
\text { Simvastatin }(2.5 \mathrm{mg} / \mathrm{kg}) \\
\text { Pravastatin }(2.5 \mathrm{mg} / \mathrm{kg}) \\
\text { Atorvastatin }(2.5 \mathrm{mg} / \mathrm{kg}) \\
\text { for } 8 \text { weeks }\end{array}$ & $\begin{array}{l}40 \% \downarrow^{*} \\
43 \% \downarrow^{*} \\
37 \% \downarrow^{*} \\
32 \% \downarrow^{*} \\
\text { (AUC) }\end{array}$ & $\begin{array}{c}39 \% \downarrow \\
41 \% \downarrow \\
13 \% \downarrow \\
69 \% \downarrow \text { } \\
\text { (Iliac-femoral artery, } \\
\text { microscopic lesion) }\end{array}$ & Bocan [58] \\
\hline $\begin{array}{l}\mathrm{JW} \\
\text { (Male) }\end{array}$ & $\begin{array}{c}0.5 \% \\
\text { cholesterol }\end{array}$ & $\begin{array}{l}\text { Fluvastain }(2 \mathrm{mg} / \mathrm{kg}) \\
\text { for } 12 \text { weeks }\end{array}$ & $\begin{array}{c}14 \% \downarrow \\
(12 \text { weeks) }\end{array}$ & $\begin{array}{c}62 \% \downarrow^{*} \\
\text { (Aorta, microscopic lesion) }\end{array}$ & $\begin{array}{l}\text { Rikitake } \\
\text { [64] }\end{array}$ \\
\hline $\begin{array}{c}\text { NZW } \\
\text { (Female) }\end{array}$ & $\begin{array}{c}0.3 \% \\
\text { cholesterol }\end{array}$ & $\begin{array}{l}\text { Pitavastatin }(0.1 \mathrm{mg} / \mathrm{kg}) \\
\text { for } 12 \text { weeks }\end{array}$ & $\begin{array}{c}27 \% \downarrow * \\
(12 \text { weeks) }\end{array}$ & $\begin{array}{c}64 \% \downarrow * \\
\text { (Aortic arch, microscopic } \\
\text { lesion) }\end{array}$ & $\begin{array}{l}\text { Hayashi } \\
\text { [65] }\end{array}$ \\
\hline \multicolumn{6}{|c|}{ WHHL rabbits } \\
\hline (Female) & $\begin{array}{l}\text { Normal } \\
\text { standard }\end{array}$ & $\begin{array}{l}\text { Lovastatin }(0.03 \% \text { diet }) \\
\text { for } 10 \text { days }\end{array}$ & $\begin{array}{c}40 \% \downarrow \\
\text { (10 days) }\end{array}$ & - & Ma [66] \\
\hline $\begin{array}{l}\text { (Male and } \\
\text { female) }\end{array}$ & $\begin{array}{l}\text { Normal } \\
\text { standard }\end{array}$ & $\begin{array}{l}\text { Pravastatin }(50 \mathrm{mg} / \mathrm{kg}) \\
\text { for } 8 \text { weeks }\end{array}$ & $\begin{array}{c}33 \% \downarrow * \\
(8 \text { weeks) }\end{array}$ & - & Tsujita [67] \\
\hline $\begin{array}{l}\text { (Male and } \\
\text { female) }\end{array}$ & $\begin{array}{l}\text { Normal } \\
\text { standard }\end{array}$ & $\begin{array}{c}\text { Pravastatin }(50 \mathrm{mg} / \mathrm{kg}) \\
\text { for } 24 \text { weeks }\end{array}$ & $\begin{array}{c}28 \% \downarrow^{*} \\
\text { (24 weeks) }\end{array}$ & $\begin{array}{c}54 \% \downarrow^{*} \\
\text { (Coronary artery, } \\
\text { microscopic lesion) }\end{array}$ & $\begin{array}{l}\text { Watanabe } \\
\text { [59] }\end{array}$ \\
\hline $\begin{array}{l}\text { (Male and } \\
\text { female) }\end{array}$ & $\begin{array}{l}\text { Normal } \\
\text { standard }\end{array}$ & $\begin{array}{l}\text { Cerivastatin }(0.6 \mathrm{mg} / \mathrm{kg}, \\
\text { subcutaneously) } \\
\text { for } 32 \text { weeks }\end{array}$ & $\begin{array}{c}39 \% \downarrow * \\
\text { (32 weeks) }\end{array}$ & $\begin{array}{c}37 \% \downarrow^{*} \\
\text { (Thoracic aorta, } \\
\text { microscopic lesion) }\end{array}$ & Shiomi [68] \\
\hline (Male) & $\begin{array}{l}\text { Normal } \\
\text { standard }\end{array}$ & $\begin{array}{l}\text { Pitavastatin }(0.5 \mathrm{mg} / \mathrm{kg}) \\
\text { for } 16 \text { weeks }\end{array}$ & $\begin{array}{c}29 \% \downarrow * \\
(16 \text { weeks) }\end{array}$ & $\begin{array}{c}39 \% \downarrow^{*} \\
\text { (Aorta, gross lesion) }\end{array}$ & Suzuki [69] \\
\hline
\end{tabular}

JW, Japanese white; NZW, New Zealand white; WHHL, Watanabe heritable hyperlipidemic; TC, total cholesterol; AUC, area under the curve of plasma TC. Plasma TC and atherosclerosis are expressed as \% compared with those of control rabbits $(* p<0.05)$.

\subsection{Fibrates}

Fibrate is an agonist of the peroxisome proliferator-activated receptor $\alpha$, which up-regulates the expression of the lipoprotein lipase, apo A-I, and apo A-II genes in the liver [70]. Fibrates are known as potent TG-lowering drugs for humans because they can reduce TG-rich lipoproteins such as CM, VLDL, and their remnants. In both humans and rodents, fibrates significantly decrease plasma TG, but this effect is either absent or only slight in rabbits [71,72]. In spite of this, Saitoh et al. reported that fibrate can exert an anti-atherosclerotic effect in cholesterol-fed NZW rabbits [73]. Corti et al. evaluated the effects of fenofibrate on atherosclerotic plaque regression using magnetic resonance imaging (MRI). Atherosclerosis was induced by balloon injury and nine-month $0.2 \%$ cholesterol diet feeding in NZW rabbits. The baseline established 
atherosclerotic burden was assessed by MRI, and then the rabbits were treated with fenofibrate for six months. Fenofibrate treatment did not change plasma LDL-C levels but increased plasma HDL-C levels. MRI analysis showed that fenofibrate treatment led to an $11 \%$ reduction in the aortic lesions compared to the pre-treatment baseline area [74]. Jeanpierre et al. examined the effect of fenofibrate on plaque thrombogenicity and plaque stability in cholesterol-fed NZW rabbits with balloon injury. Fenofibrate significantly decreased tissue factor expression ( $42 \%$ reduction) and plaque cholesterol content (45\% reduction) in the iliac artery of rabbits [75].

\subsection{Ezetimibe}

Ezetimibe is an inhibitor of cholesterol absorption through the targeting of Nieman Pick C1 like 1 protein at the brush border of intestinal epithelial cells. Ezetimibe is often prescribed for patients with elevated plasma TC, LDL-C, and apo B, either as monotherapy or in combination with statins [76]. The pharmacological functions of ezetimibe on atherosclerosis, thrombosis, and fatty liver disease have been investigated in rabbits (Table 2). Gómez-Garre et al. examined the effect of ezetimibe combined with simvastatin on cholesterol-fed rabbits with femoral artery injury. Although ezetimibe did not significantly change plasma TC levels, the intima/media ratio of the femoral artery was reduced by $13 \%$ (ezetimibe), $27 \%$ (simvastatin), and 28\% (ezetimibe plus simvastatin) compared with that of control rabbits [77]. Patel et al. evaluated the effect of ezetimibe on atherothrombosis [78]. Atherosclerosis was induced by cholesterol diet feeding and balloon injury, and then plaque disruption and thrombosis were triggered by Russell's viper venom and histamine. Ezetimibe treatment reduced plasma TC levels and decreased plaque size and thrombus area [78]. Honda et al. recently showed that ezetimibe treatment significantly decreased thrombus occlusion in the femoral artery in angiotensin II-perfused rabbits [79]. In addition, Ogawa et al. examined the effect of ezetimibe on rabbits with nonalcoholic steatohepatitis, which was induced by feeding a diet containing $1.25 \%$ cholesterol and $20 \%$ corn oil. Ezetimibe therapy lowered plasma TC levels and suppressed hepatic fat depositions and fibrosis [80].

Table 2. Ezetimibe in rabbit models.

\begin{tabular}{|c|c|c|c|c|}
\hline $\begin{array}{c}\text { Target Disease } \\
\text { Rabbit and Manipulation }\end{array}$ & Drug & Plasma TC & Outcome & Reference \\
\hline $\begin{array}{l}\text { Atherosclerosis } \\
\text { - } \quad \mathrm{NZW} \mathrm{(male)} \\
\text { - } \quad 2 \% \text { Chol, 6\% peanut oil diet } \\
\text { - } \quad \text { Endothelial desiccation }\end{array}$ & $\begin{array}{c}\text { Ezetimibe }(0.6 \mathrm{mg} / \mathrm{kg}) \\
\text { Simvastatin }(5 \mathrm{mg} / \mathrm{kg}) \\
\text { Combination }(\text { Eze }+\mathrm{Sim}) \\
\text { for } 6 \text { weeks }\end{array}$ & $\begin{array}{c}8 \% \downarrow \\
26 \% \downarrow \\
37 \% \downarrow \\
\text { (6 weeks) }\end{array}$ & $\begin{array}{c}13 \% \downarrow^{*} \\
27 \% \downarrow^{*} \\
28 \% \downarrow^{*} \\
\text { (Femoral artery, } \\
\text { intima/media ratio) }\end{array}$ & $\begin{array}{c}\text { Gómez-Garre } \\
\text { [77] }\end{array}$ \\
\hline $\begin{array}{l}\text { Atherothrombosis } \\
\text { - } \quad \text { NZW (male) } \\
\text { - } 1 \% \text { Chol diet (alternating } \\
\text { with normal chow every } \\
\text { other month) } \\
\text { - } \quad \text { Balloon denudation } \\
\text { Pharmacologically triggered } \\
\text { plaque disruption }\end{array}$ & $\begin{array}{l}\text { Ezetimibe }(1 \mathrm{mg} / \mathrm{kg}) \\
\text { for } 3 \text { months }\end{array}$ & $\begin{array}{c}86 \% \downarrow{ }^{*} \\
(6 \text { months })\end{array}$ & $\begin{array}{l}\text { Plaque area: } 38 \% \downarrow^{*} \\
\text { Thrombus area: } 93 \% \downarrow^{*}\end{array}$ & Patel [78] \\
\hline 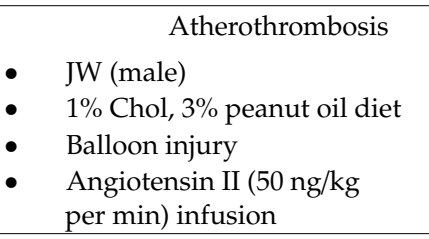 & $\begin{array}{l}\text { Ezetimibe }(0.6 \mathrm{mg} / \mathrm{kg}) \\
\text { Rosvastatin }(1 \mathrm{mg} / \mathrm{kg}) \\
\quad \text { for } 2-8 \text { weeks }\end{array}$ & $\begin{array}{c}18 \% \downarrow^{*} \\
23 \% \downarrow^{*} \\
\text { (4 weeks) }\end{array}$ & $\begin{array}{c}51 \% \downarrow^{*} \\
12 \% \downarrow \\
\text { (Thrombotic occlusion) }\end{array}$ & Honda [79] \\
\hline \begin{tabular}{l}
\multicolumn{2}{c}{ NASH } \\
- $\quad \mathrm{JW}$ (male) \\
- $1.25 \%$ Chol, $20 \%$ corn oil diet \\
\end{tabular} & $\begin{array}{c}\text { Ezetimibe }(0.6 \mathrm{mg} / \mathrm{kg}) \\
\text { for } 8 \text { weeks }\end{array}$ & $\begin{array}{l}\approx 40 \% \downarrow * \\
(8 \text { weeks) }\end{array}$ & $\begin{array}{l}\text { Lipid droplet: } \approx 15 \% \downarrow^{*} \\
\text { Hepatic TC: } \approx 26 \% \downarrow^{*} \\
\text { Hepatic TG: } \approx 63 \% \downarrow^{*}\end{array}$ & Ogawa [80] \\
\hline
\end{tabular}

NZW, New Zealand white; JW, Japanese white; Chol, cholesterol; NASH, nonalcoholic steatohepatitis; TC, total cholesterol; TG, triglycerides. Plasma TC and outcomes are expressed as \% compared with those of control rabbits $(* p<0.05)$. 


\subsection{Probucol}

Probucol was originally synthesized in the 1970s as an anti-oxidant and was subsequently found to have lipid-lowering effects [81]. Although the lipid-lowering effect is relatively mild compared to statins, probucol possesses strong anti-oxidative activity along with HDL-lowering and anti-atherosclerotic effects [82]. Probucol was prescribed in the 1980s before the birth of statin. Since probucol is notorious for its HDL-lowering effect, probucol is now used only in Asian countries such as Japan, Korea, and China. The anti-atherosclerotic effect of probucol has been well characterized in cholesterol-fed and WHHL rabbits. Pharmacological effects of probucol on the lipoprotein profiles and atherosclerosis are summarized in Table 3. Naruszewicz et al. reported that probucol reduced LDL-C and HDL-C in WHHL rabbits [83]. Kita et al. and Carew et al. demonstrated an anti-atherosclerotic effect of probucol in WHHL rabbits [84,85]. Although the reduction in plasma TC levels was quite mild, probucol-treated WHHL rabbits showed a significant reduction in aortic atherosclerosis [84,85]. Daugherty et al. tested the anti-atherosclerotic effect of probucol on a cholesterol-fed rabbit model and showed that probucol treatment protected against lesion progression without affecting plasma TC levels [86]. Oshima et al. reported that probucol treatment led to the regression of the established aortic atherosclerosis in WHHL rabbits [87]; however, others failed to reproduce the results [88]. We have shown that probucol can also inhibit the initiation of atherosclerosis by reducing monocyte adherence and infiltration into the subintima [89]. Furthermore, probucol reduces coronary atherosclerosis and stabilizes plaques in WHHL rabbits [90]. The anti-atherosclerotic effect of probucol occurs mainly through its anti-oxidative activity on LDL [91]. In fact, $69 \%$ of probucol in plasma was distributed on the LDL particles in WHHL rabbits [84].

Table 3. Pharmacological effects of probucol in rabbit models.

\begin{tabular}{|c|c|c|c|c|c|}
\hline Rabbit & Drug & Plasma Lipids & Atherosclerosis & Findings & Reference \\
\hline \multicolumn{6}{|c|}{ WHHL rabbits (Normal standard diet) } \\
\hline $\begin{array}{l}\text { (Male and } \\
\text { female) }\end{array}$ & $\begin{array}{l}1 \% \text { probucol } \\
\text { in diet } \\
\text { (4 weeks) }\end{array}$ & $\begin{array}{c}\text { TC: } 24 \% \downarrow \\
\text { VLDL-C: } 4 \% \downarrow \\
\text { IDL-C: } 2 \% \downarrow \\
\text { LDL-C: } 36 \% \downarrow \\
\text { HDL-C: } 53 \% \downarrow \\
\text { (4 weeks vs. } \\
\text { pre-treatment) }\end{array}$ & - & $\begin{array}{l}\text { up-regulation of LDL } \\
\text { fractional catabolic rate }\end{array}$ & $\begin{array}{c}\text { Naruszewicz } \\
{[83]}\end{array}$ \\
\hline $\begin{array}{l}\text { (Male and } \\
\text { female) }\end{array}$ & $\begin{array}{l}1 \% \text { probucol } \\
\text { in diet } \\
(6 \text { months })\end{array}$ & $\begin{array}{l}\text { TC: } 17 \% \downarrow \\
\text { (6 months) }\end{array}$ & $\begin{array}{c}87 \% \downarrow^{*} \\
\text { (Thoracic aorta, } \\
\text { gross lesion) }\end{array}$ & $\begin{array}{l}\text { protective effect of } \\
\text { LDL oxidization }\end{array}$ & Kita [84] \\
\hline $\begin{array}{l}\text { (Male and } \\
\text { female) }\end{array}$ & $\begin{array}{l}1 \% \text { probucol } \\
\text { in diet } \\
(\approx 33 \text { weeks })\end{array}$ & $\begin{array}{l}\text { TC: } 12 \% \downarrow \\
\text { (during } \\
\text { treatment) }\end{array}$ & $\begin{array}{c}65 \% \downarrow^{*} \\
\text { (Aorta, gross lesion) }\end{array}$ & $\begin{array}{l}\text { protective effect of } \\
\text { lesional LDL } \\
\text { degradation }\end{array}$ & Carew [85] \\
\hline (Male) & $\begin{array}{l}1 \% \text { probucol } \\
\text { in diet } \\
\text { (5 months) }\end{array}$ & $\begin{array}{c}\text { TC: } 35 \% \downarrow^{*} \\
\text { VLDL-C: } 51 \% \downarrow^{*} \\
\text { IDL-C: } 19 \% \downarrow \\
\text { LDL-C: } 33 \% \downarrow^{*} \\
\text { HDL-C: } 45 \% \downarrow^{*} \\
\text { (5 months) }\end{array}$ & $\begin{array}{c}\approx 39 \% \downarrow^{*} \\
\text { (Aorta, gross lesion) }\end{array}$ & $\begin{array}{c}\text { regression of } \\
\text { atherosclerosis } \\
\left(\approx 34 \% \downarrow^{*} \text { vs. baseline }\right. \\
\text { lesion })\end{array}$ & Oshima [87] \\
\hline (Male) & $\begin{array}{c}0.3 \% \\
\text { probucol in } \\
\text { diet } \\
\text { (16 weeks) }\end{array}$ & $\begin{array}{l}\text { TC: } 12 \% \downarrow * \\
\text { HDL-C: } 12 \% \downarrow \\
\text { (16 weeks) }\end{array}$ & $\begin{array}{c}41 \% \downarrow^{*} \\
\text { (Coronary artery, } \\
\text { stenosis) }\end{array}$ & $\begin{array}{l}\text { protective effect of } \\
\text { coronary } \\
\text { atherosclerosis }\end{array}$ & $\operatorname{Li}[90]$ \\
\hline
\end{tabular}


Table 3. Cont.

\begin{tabular}{|c|c|c|c|c|c|}
\hline Rabbit & Drug & Plasma Lipids & Atherosclerosis & Findings & Reference \\
\hline \multicolumn{6}{|c|}{ Wild-type rabbits (Cholesterol diet) } \\
\hline $\begin{array}{c}\text { NZW } \\
2 \% \text { Chol diet }\end{array}$ & $\begin{array}{l}1 \% \text { probucol } \\
\text { in diet } \\
\text { (60 days) }\end{array}$ & $\begin{array}{l}\text { TC: } 16 \% \downarrow \\
\text { (60 days) }\end{array}$ & $\begin{array}{l}\text { Thoracic: } 79 \% \downarrow^{*} \\
\text { Abdominal: } 85 \% \downarrow^{*} \\
\text { (Aorta, gross lesion) }\end{array}$ & $\begin{array}{l}\text { anti-atherosclerotic } \\
\text { effect without plasma } \\
\text { lipid lowering }\end{array}$ & $\begin{array}{c}\text { Daugherty } \\
\text { [86] }\end{array}$ \\
\hline $\begin{array}{c}\text { NZW } \\
\text { (male) } \\
0.5 \% \text { Chol diet }\end{array}$ & $\begin{array}{c}0.3 \% \\
\text { probucol in } \\
\text { diet } \\
\text { (4 weeks) }\end{array}$ & $\begin{array}{c}\text { TC: } 4 \% \downarrow \\
\text { HDL-C: } 49 \% \downarrow * \\
\text { (5 weeks) }\end{array}$ & $\begin{array}{c}65 \% \downarrow^{*} \\
\text { (Aorta, gross lesion) }\end{array}$ & $\begin{array}{l}\text { protective effect of } \\
\text { initial atherosclerosis }\end{array}$ & Niimi [89] \\
\hline $\begin{array}{l}\text { WHHL, Wat } \\
\text { VLDL-C, ve } \\
\text { LDL-C, low- } \\
\text { atheroscleros }\end{array}$ & $\begin{array}{l}\text { be heritable } \mathrm{h} \\
\text { low-density } \\
\text { sity lipoprot } \\
\text { re expressed a }\end{array}$ & $\begin{array}{l}\text { erlipidemic; NZV } \\
\text { oprotein cholest } \\
\text { cholesterol; HDI } \\
\text { o compared with }\end{array}$ & $\begin{array}{l}\text { New Zealand white; } \\
\text { l; IDL-C, intermed } \\
\text {, high-density lipopr } \\
\text { se of control rabbits (* }\end{array}$ & $\begin{array}{l}\text { l, cholesterol; TC, total } \\
\text { e-density lipoprotein } \\
\text { in cholesterol. Plasma } \\
<0.05) \text {. }\end{array}$ & $\begin{array}{l}\text { olesterol; } \\
\text { olesterol; } \\
\text { pids and }\end{array}$ \\
\hline
\end{tabular}

\subsection{CETP Inhibitors}

Epidemiological studies have demonstrated that lower plasma HDL-C is associated with increased coronary heart disease (CHD) risk [92]. Therefore, for a long time, it has been hypothesized that elevated plasma HDL-C levels may be beneficial to cardiovascular functions. CETP is a plasma protein that facilitates the transport of cholesteryl ester and triglycerides between the lipoproteins. It collects triglycerides from VLDL or LDL and exchanges them for cholesteryl ester from HDL, and vice versa. CETP inhibitors prevent the transfer of cholesteryl ester and increases plasma HDL-C levels; therefore, their use is intended to reduce the risk of atherosclerosis by improving blood lipid levels [93]. Until now, several CETP inhibitors have been developed. Interestingly, CETP only exists in humans and a few laboratory animals, such as rabbits, guinea pigs, and hamsters, whereas mice and rats do not have CETP [9]. To study the functions of CETP and its inhibitors, rabbits are often used. The effects of CETP inhibitors in rabbits are summarized in Table 4. Many studies showed that administration with these CETP inhibitors effectively increased plasma HDL-C in rabbit models [94-99]. Dalcetrapib administration mildly reduced plasma TC levels in cholesterol-fed rabbits $[96,97]$. Furthermore, dalcetrapib, torcetrapib, and K-312 showed an atheroprotective effect in cholesterol-fed rabbits $[96,98,99]$. Our laboratory also demonstrated that genetic ablation of the CETP gene in rabbits led to increased plasma HDL-C and lowered plasma TC levels, and it protected against diet-induced atherosclerosis [100]. In the early clinical trials, four CETP inhibitors, namely torcetrapib, dalcetrapib, anacetrapib, and evacetrapib, could significantly elevate plasma HDL-C levels. Although clinical trials with three other inhibitors failed to show any beneficial effect for $\mathrm{CHD}$, anacetrapib decreased the incidence of CHD [101].

Table 4. Effects of cholesteryl ester transfer protein (CETP) inhibitors in rabbit models.

\begin{tabular}{|c|c|c|c|c|c|c|}
\hline \multirow{2}{*}{ Rabbit } & \multirow{2}{*}{ Drug } & \multicolumn{3}{|c|}{ Plasma Lipids } & \multirow{2}{*}{ Atherosclerosis } & \multirow{2}{*}{ Reference } \\
\hline & & HDL-C & LDL-C & TC & & \\
\hline \multicolumn{7}{|c|}{ Normal standard diet } \\
\hline JW (male) & $\begin{array}{c}\text { Dalcetrapib }(300 \mathrm{mg} / \mathrm{kg}) \\
\text { for } 7 \text { days }\end{array}$ & $\begin{array}{l}2.1 \text {-fold } \uparrow * \\
(7 \text { days })\end{array}$ & $\begin{array}{c}4 \% \uparrow \\
\text { (7 days) }\end{array}$ & $\begin{array}{l}73 \% \uparrow * \\
(7 \text { days })\end{array}$ & - & $\begin{array}{c}\text { Kobayashi } \\
\text { [94] }\end{array}$ \\
\hline NZW (male) & $\begin{array}{l}\text { Dalcetrapib }(300 \mathrm{mg} / \mathrm{kg}) \\
\text { Anacetrapib }(30 \mathrm{mg} / \mathrm{kg}) \\
\text { for } 2 \text { weeks }\end{array}$ & $\begin{array}{l}\text { 3.3-fold } \uparrow * \\
2.7 \text {-fold } \uparrow * \\
\text { (2 weeks) }\end{array}$ & $\begin{array}{c}7 \% \uparrow \\
21 \% \uparrow \\
\text { (2 weeks) }\end{array}$ & $\begin{array}{c}86 \% \uparrow * \\
72 \% \uparrow * \\
\text { (2 weeks) }\end{array}$ & - & Brodeur [95] \\
\hline \multicolumn{7}{|c|}{ High-cholesterol diet } \\
\hline $\begin{array}{c}\text { JW (male) } \\
0.2 \% \text { Chol diet }\end{array}$ & $\begin{array}{c}\text { Dalcetrapib } \\
(\approx 225 \mathrm{mg} / \mathrm{kg}) \\
\text { for } 6 \text { months }\end{array}$ & $\begin{array}{l}2.0 \text {-fold } \uparrow * \\
\text { (6 months) }\end{array}$ & - & $\begin{array}{c}24 \% \downarrow \\
\text { (6 months) }\end{array}$ & $\begin{array}{c}70 \% \downarrow^{*} \\
\text { (Aortic arch, } \\
\text { gross lesion) }\end{array}$ & $\begin{array}{c}\text { Okamoto } \\
{[96]}\end{array}$ \\
\hline
\end{tabular}


Table 4. Cont.

\begin{tabular}{|c|c|c|c|c|c|c|}
\hline \multirow{2}{*}{ Rabbit } & \multirow{2}{*}{ Drug } & \multicolumn{3}{|c|}{ Plasma Lipids } & \multirow{2}{*}{ Atherosclerosis } & \multirow{2}{*}{ Reference } \\
\hline & & HDL-C & LDL-C & TC & & \\
\hline $\begin{array}{c}\text { JW (male) } \\
0.25 \% \text { Chol diet }\end{array}$ & $\begin{array}{l}\text { Dalcetrapib }(100 \mathrm{mg} / \mathrm{kg}) \\
\text { Dalcetrapib }(300 \mathrm{mg} / \mathrm{kg}) \\
\text { for } 12 \text { weeks }\end{array}$ & $\begin{array}{l}\text { 1.3-fold } \uparrow \\
1.9 \text {-fold } \uparrow * \\
\text { (12 weeks) }\end{array}$ & - & $\begin{array}{c}6 \% \downarrow \\
21 \% \downarrow \\
\text { (12 weeks) }\end{array}$ & $\begin{array}{c}12 \% \uparrow \\
3 \% \uparrow \\
\text { (Aorta, } \\
\text { gross lesion) }\end{array}$ & Huang [97] \\
\hline $\begin{array}{c}\text { NZW (male) } \\
0.2 \% \text { Chol, } 10 \% \\
\text { coconut oil diet }\end{array}$ & $\begin{array}{l}\text { Torcetrapib } \\
(60-90 \mathrm{mg} / \mathrm{kg}) \\
\text { for } 16 \text { weeks }\end{array}$ & $\begin{array}{l}\text { 3.6-fold } \uparrow \\
\text { (16 weeks) }\end{array}$ & - & $\begin{array}{c}28 \% \uparrow \\
\text { (16 weeks) }\end{array}$ & $\begin{array}{c}59 \% \downarrow^{*} \\
\text { (Aorta, } \\
\text { gross lesion) }\end{array}$ & $\begin{array}{c}\text { Morehouse } \\
\text { [98] }\end{array}$ \\
\hline $\begin{array}{c}\text { NZW (male) } \\
0.25 \% \text { Chol diet }\end{array}$ & $\begin{array}{l}\mathrm{K}-312(10 \mathrm{mg} / \mathrm{kg}) \\
\mathrm{K}-312(30 \mathrm{mg} / \mathrm{kg}) \\
\text { for } 18 \text { weeks }\end{array}$ & $\begin{array}{l}\approx 4.7 \text {-fold } \uparrow * \\
\approx 5.1 \text {-fold } \uparrow * \\
\text { (18 weeks) }\end{array}$ & $\begin{array}{c}\approx 33 \% \uparrow \\
\approx 18 \% \uparrow \\
\text { (18 weeks) }\end{array}$ & - & $\begin{array}{c}\approx 54 \% \downarrow^{*} \\
\approx 55 \% \downarrow * \\
\quad \text { (Aorta, } \\
\text { gross lesion) }\end{array}$ & $\begin{array}{c}\text { Miyosawa } \\
\text { [99] }\end{array}$ \\
\hline
\end{tabular}

JW, Japanese white; NZW, New Zealand white; Chol, cholesterol; HDL-C, high-density lipoprotein cholesterol;

LDL-C, low-density lipoprotein cholesterol; TC, total cholesterol. Plasma lipids and atherosclerosis are expressed as

$\%$ or fold-change compared with those of control rabbits $\left({ }^{*} p<0.05\right)$.

\subsection{HDL, Apo A-I, Apo A-I Milano, and Apo A-I Mimetic Peptides}

HDL, especially its compositional protein apo A-I, possesses a number of physiological functions to protect against atherosclerosis, including reverse cholesterol transport, anti-inflammation, anti-oxidization, mediation of vascular tone, and anti-thrombosis [102-104]. The concept of elevation of plasma HDL or apo A-I to reduce cardiovascular risk has been suggested by both clinical and experimental studies. Many of these experiments were performed in hypercholesterolemic rabbits, using either HDL or apo A-I (including apo A-I variants and apo A-I mimetic peptides), as summarized in Table 5.

Badimon et al. first examined the effect of HDL administration in cholesterol-fed rabbits. A plasma HDL-VHDL $(\mathrm{d}=1.063-1.21 \mathrm{~g} / \mathrm{mL}$ and $\mathrm{d}=1.21-1.25 \mathrm{~g} / \mathrm{mL})$ fraction was isolated from normal rabbits. HDL-VHDL was administrated intravenously to $0.5 \%$ cholesterol-fed rabbits for eight weeks. HDL-VHDL treatment led to a $61 \%$ reduction in aortic atherosclerosis over the control [105]. Badimon et al. also demonstrated that such treatment can result in the regression of aortic atherosclerosis (48\% reduction) [106]. Most recently, Ben-Aicha et al. compared the atheroprotective properties of HDLs isolated from normolipidemic and hyperlipidemic rabbits. Atherosclerosis was induced by a combination of cholesterol diet feeding and balloon injury. Administration of HDL from normolipidemic rabbits regressed aortic lesions by $4.3 \%$ compared with the baseline, whereas HDL from hyperlipidemia increased the lesions by $6.5 \%$ [107].

Direct injection of apo A-I into rabbits to test the atheroprotective effects has been attempted. For example, Miyazaki et al. showed that injection with purified rabbit apo A-I significantly reduced atherosclerosis by $48 \%$ over the control rabbits [108]. Soma et al. generated carotid atherosclerosis by an extra-arterial collar placement in 1\% cholesterol-fed rabbits, and administration of the apo

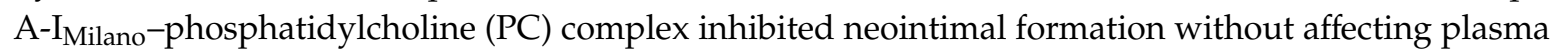
TC levels [109]. Chiesa et al. evaluated whether apo A- $\mathrm{I}_{\text {Milano }}$ mobilizes lipids from carotid artery fatty streaks. Lipid-rich plaques were generated at common carotid arteries by a perivascular electrical injury, followed by $1.5 \%$ cholesterol diet for 90 days. The effect of apo A-I $\mathrm{I}_{\text {Milano-phospholipid }}$ complex administration was assessed by intravascular ultrasound. A single administration of

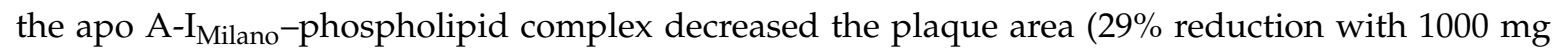
dose) by the end of the 90-min infusion compared with the pre-infusion [110]. Ibanez et al. reported a plaque regression effect of apo A-I $\mathrm{I}_{\text {Milano }}$ using MRI. Abdominal aortic atherosclerosis was induced by a combination of nine-month $0.2 \%$ cholesterol-rich diet and twice aortic balloon

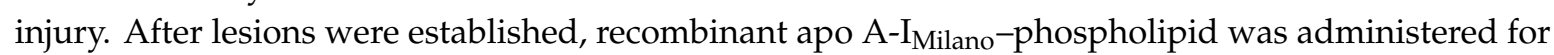

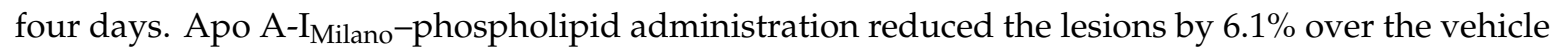
control and 5.1\% compared with baseline [111]. In addition, transgenic expression of human apo A-I and apo A-II also protects against diet-induced atherosclerosis [112,113]. 
The apo A-I mimetic peptide, 18-amino acid peptide (18A), was originally designed as a model peptide of the class A amphipathic helix by Anantharamaiah in the 1980s [114]. 18A with PC formed a discoidal complex, which was structurally similar to apo A-I. The 18A-PC complex showed similar functions to apo A-I such as cellular cholesterol efflux, activation of lecithin-cholesterol acyltransferase activity, and anti-inflammatory effects. The structure of $18 \mathrm{~A}$ was refined and derivative peptides were synthesized, including Ac- $18 \mathrm{~A}-\mathrm{NH}_{2}, 4 \mathrm{~F}, 5 \mathrm{~F}$, and Ac-hE18A- $\mathrm{NH}_{2}$ [115]. To evaluate the effects of lipid metabolism and atherosclerosis, mimetic peptides were tested in rabbits [116-118]. Van Lenten et al. and Iwata et al. showed anti-atherosclerotic effects of the apo A-I mimetic peptide in cholesterol-fed [117] and WHHL rabbits [118].

Table 5. HDL or apo A-I therapeutics tested in rabbit models.

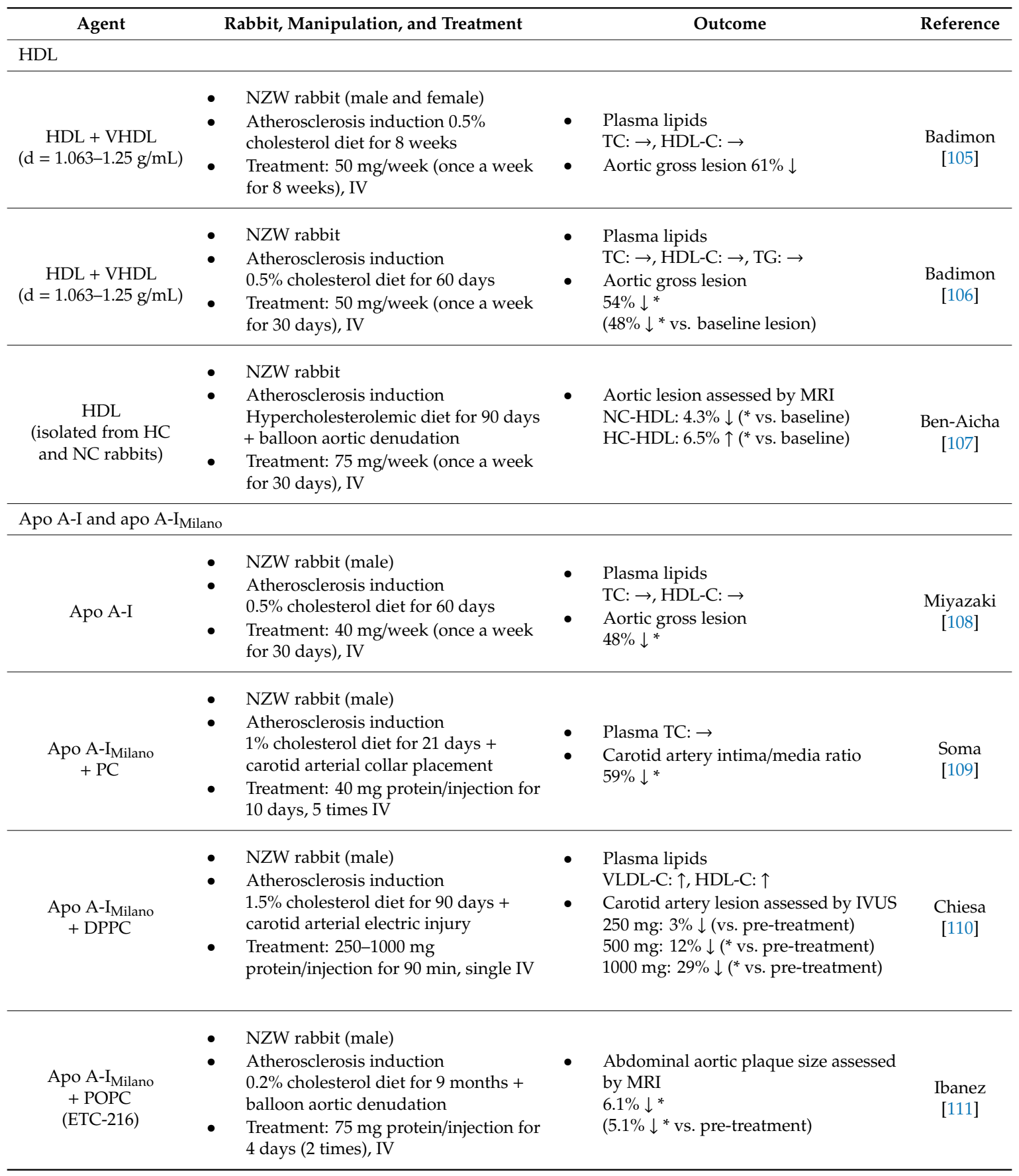


Table 5. Cont.

\begin{tabular}{|c|c|c|c|}
\hline Agent & Rabbit, Manipulation, and Treatment & Outcome & Reference \\
\hline \multicolumn{4}{|c|}{ Apo A-I mimetic peptide } \\
\hline Ac-hE18A-NH$H_{2}$ & $\begin{array}{ll}\text { - } & \text { WHHL rabbit (male) } \\
\text { - } & \text { Treatment: } 15 \mathrm{mg} / \mathrm{kg} \text { for } 18 \mathrm{~h} \text {, single IV }\end{array}$ & $\begin{array}{l}\text { - } \quad \text { Plasma TC } \\
49 \% \downarrow\left({ }^{*} \text { vs. pre-treatment }\right)\end{array}$ & $\begin{array}{l}\text { Gupta } \\
\text { [116] }\end{array}$ \\
\hline $\begin{array}{l}\mathrm{D}-4 \mathrm{~F} \\
\mathrm{~L}-4 \mathrm{~F}\end{array}$ & $\begin{array}{l}\text { - } \quad \text { NZW (female) } \\
\text { Atherosclerosis induction } \\
\text { 1\% cholesterol diet for } 1 \text { month } \\
\text { Treatment: } 10 \mathrm{mg} / \mathrm{kg} / \text { day (daily for } \\
1 \text { month), SC }\end{array}$ & $\begin{array}{l}\text { - } \quad \text { Plasma lipids (2 months) } \\
\text { TC: } 19 \% \downarrow^{*}(\mathrm{D}-4 \mathrm{~F}), 28 \% \downarrow^{*} \\
\text { (L-4F)HDL-C: } \rightarrow(\mathrm{D}-4 \mathrm{~F}, \mathrm{~L}-4 \mathrm{~F}) \\
\text { Aortic gross lesion } 58 \% \downarrow^{*}(\mathrm{D}-4 \mathrm{~F}), 46 \% \\
\downarrow^{*}(\mathrm{~L}-4 \mathrm{~F})\end{array}$ & $\begin{array}{c}\text { Van } \\
\text { Lenten } \\
\text { [117] }\end{array}$ \\
\hline $\begin{array}{l}\text { EPS } 24218 \\
+ \text { DPPC } \\
\quad+\text { SM } \\
(\text { ETC-462) }\end{array}$ & $\begin{array}{l}\text { - WHHL rabbit (male and female) } \\
\text { - Treatment: } 50 \mathrm{mg} / \mathrm{kg} \text { (twice a week for } \\
12 \text { weeks), IV }\end{array}$ & $\begin{array}{l}\text { - } \quad \text { Plasma lipids (12 weeks) } \\
\text { TC: } 22 \% \uparrow * \\
\text { LDL-C: } 30 \% \downarrow^{*} \\
\text { HDL-C: } 30 \% \uparrow^{*} \\
\text { - } \quad \text { Aortic lesion volume assessed by IVUS } \\
25 \% \downarrow^{*} \\
\text { (7\% } \downarrow \text { vs. pre-treatment) }\end{array}$ & $\begin{array}{l}\text { Iwata } \\
{[118]}\end{array}$ \\
\hline
\end{tabular}

HDL, high-density lipoprotein; VHDL, very-high-density lipoprotein; apo, apolipoprotein; HC, hypercholesterolemic; NC, normocholesterolemic; PC, phosphatidylcholine; DPPC, dipalmitoyl phosphatidylcholine; POPC, palmitoyl-2-oleoyl phosphatidylcholine; SM, sphingomyelin; NZW, New Zealand white; WHHL, Watanabe heritable hyperlipidemic; IV, intravenous injection; SC, subcutaneous injection; TC, total cholesterol; HDL-C, high-density lipoprotein cholesterol; VLDL-C, very-low-density lipoprotein cholesterol; MRI, magnetic resonance imaging; IVUS, intravascular ultrasound. Outcomes are expressed as \% compared with those of vehicle control rabbits or baseline pre-treatment $\left({ }^{*} p<0.05\right)$.

\section{Limitation of Rabbit Models}

Rabbits have a number of advantages to study hyperlipidemia and for drug development. However, some limitations should be considered when using rabbit models. Unlike mice, laboratory rabbits are generally outbred. Thus, commercial rabbits may show variations in responses to a cholesterol diet and plasma lipid levels $[119,120]$. Such variations in lipids will certainly affect the extent of atherosclerosis and interfere with the evaluation of drug effects. To minimize the variation, rabbits can be prescreened by feeding them a cholesterol diet for a short term in advance, and then only those rabbits with high plasma lipid levels can be selected [89,121]. Hepatic lipase (HL) activity in the post-heparin plasma of rabbits is naturally lower than that in humans and rodents [122,123]. A recently developed automated assay for measuring HL activity revealed that HL activities in the post-heparin plasma of rats and humans are 10-fold and 4-fold higher than those of rabbits [124].

\section{Conclusions}

Rabbits are still an important model for the study of lipid metabolism and atherosclerosis. Rabbits have a number of unique features that make them useful for hypolipidemic drug development. The emergence of genome editing technology will enable us to generate more $\mathrm{KO} / \mathrm{knock}$-in rabbits for the study of hyperlipidemia and atherosclerosis. These gene-manipulated rabbits will certainly provide novel insights not only into molecular mechanisms of hyperlipidemia but also into the development of therapeutic strategies.

Author Contributions: Conceptualization, M.N. and J.F.; writing-original draft preparation, M.N.; writing - review and editing, Y.C., H.Y., Y.W., T.K. and J.F. All authors have read and agreed to the published version of the manuscript.

Funding: This work was supported in part by research grants from JSPS KAKENHI (JP20K08858), the National Natural Science Foundation of China (81941001 and 81770457), and the JSPS-CAS Bilateral Joint Research Program (JPJSBP 120187204).

Conflicts of Interest: The authors declare no conflict of interest. 


\section{Abbreviations}

$\begin{array}{ll}\text { Apo } & \text { apolipoprotein } \\ \text { CETP } & \text { cholesteryl ester transfer protein } \\ \text { CHD } & \text { coronary heart disease } \\ \text { CM } & \text { chylomicron } \\ \text { FH } & \text { familial hypercholesterolemia } \\ \text { HDL } & \text { high-density lipoprotein } \\ \text { HDL-C } & \text { high-density lipoprotein cholesterol } \\ \text { HL } & \text { hepatic lipase } \\ \text { JW } & \text { Japanese white } \\ \text { KO } & \text { knockout } \\ \text { LDL } & \text { low-density lipoprotein } \\ \text { LDL-C } & \text { low-density lipoprotein cholesterol } \\ \text { LDLR } & \text { low-density lipoprotein receptor } \\ \text { MRI } & \text { magnetic resonance imaging } \\ \text { NZW } & \text { New Zealand white } \\ \text { PC } & \text { phosphatidylcholine } \\ \text { TC } & \text { total cholesterol } \\ \text { TG } & \text { triglycerides } \\ \text { Tg } & \text { transgenic } \\ \text { VHDL } & \text { very-high-density lipoprotein } \\ \text { VLDL } & \text { very-low-density lipoprotein } \\ \text { VLDL-C } & \text { very-low-density lipoprotein cholesterol } \\ \text { WHHL } & \text { Watanabe heritable hyperlipidemic } \\ \text { WHHLMI } & \text { myocardial infarction-prone Watanabe heritable hyperlipidemic } \\ \end{array}$

\section{References}

1. Ross, R. Atherosclerosis-An Inflammatory Disease. N. Engl. J. Med. 1999, 340, 115-126. [CrossRef]

2. Hansson, G.K. Inflammation, Atherosclerosis, and Coronary Artery Disease. N. Engl. J. Med. 2005, 352, 1685-1695. [CrossRef]

3. Beaumont, J.L.; Carlson, L.A.; Cooper, G.R.; Fejfar, Z.; Fredrickson, D.S.; Strasser, T. Classification of hyperlipidaemias and hyperlipoproteinaemias. Bull. World Health Organ. 1970, 43, 891-915. [CrossRef]

4. Fan, J.; Chen, Y.; Yan, H.; Niimi, M.; Wang, Y.; Liang, J. Principles and applications of rabbit models for atherosclerosis research. J. Atheroscler. Thromb. 2018, 25, 213-220. [CrossRef]

5. Duff, G.L. Experimental cholesterol arteriosclerosis and its relationship to human arteriosclerosis. Arch. Pathol. 1935, 20, 81-123.

6. Zhang, S.H.; Reddick, R.L.; Piedrahita, J.A.; Maeda, N. Spontaneous hypercholesterolemia and arterial lesions in mice lacking apolipoprotein E. Science 1992, 258, 468-471. [CrossRef]

7. Ishibashi, S.; Brown, M.S.; Goldstein, J.L.; Gerard, R.D.; Hammer, R.E.; Herz, J. Hypercholesterolemia in low density lipoprotein receptor knockout mice and its reversal by adenovirus-mediated gene delivery. J. Clin. Investig. 1993, 92, 883-893. [CrossRef]

8. Fan, J.; Kitajima, S.; Watanabe, T.; Xu, J.; Zhang, J.; Liu, E.; Chen, Y.E. Rabbit models for the study of human atherosclerosis: From pathophysiological mechanisms to translational medicine. Pharmacol. Ther. 2015, 146, 104-119. [CrossRef]

9. Ha, Y.; Barter, P. Differences in plasma cholesteryl ester transfer activity in sixteen vertebrate species. Comp. Biochem. Physiol. Part B Biochem. 1982, 71, 265-269. [CrossRef]

10. Greeve, J.; Altkemper, I.; Dieterich, J.H.; Greten, H.; Windler, E. Apolipoprotein B mRNA editing in 12 different mammalian species: Hepatic expression is reflected in low concentrations of apoB-containing plasma lipoproteins. J. Lipid Res. 1993, 34, 1367-1383.

11. Steinberg, D. Thematic review series: Living history of lipids: In celebration of the 100th anniversary of the lipid hypothesis of atherosclerosis. J. Lipid Res. 2013, 54, 2946-2949. [CrossRef] 
12. Fan, J.; Watanabe, T. Cholesterol-fed and transgenic rabbit models for the study of atherosclerosis. J. Atheroscler. Thromb. 2000, 7, 26-32. [CrossRef]

13. Kolodgie, F.D.; Katocs, A.S.; Largis, E.E.; Wrenn, S.M.; Cornhill, J.F.; Herderick, E.E.; Lee, S.J.; Virmani, R. Hypercholesterolemia in the Rabbit Induced by Feeding Graded Amounts of Low-Level Cholesterol. Arterioscler. Thromb. Vasc. Biol. 1996, 16, 1454-1464. [CrossRef]

14. Mahley, R.W.; Innerarity, T.L.; Brown, M.S.; Ho, Y.K.; Goldstein, J.L. Cholesteryl ester synthesis in macrophages: Stimulation by beta-very low density lipoproteins from cholesterol-fed animals of several species. J. Lipid Res. 1980, 21, 970-980.

15. Keyamura, Y.; Nagano, C.; Kohashi, M.; Niimi, M.; Nozako, M.; Koyama, T.; Itabe, H.; Yoshikawa, T. Dietary cholesterol atherogenic changes in juvenile rabbits. Biol. Pharm. Bull. 2015, 38, 785-788. [CrossRef]

16. Huff, M.W.; Hamilton, R.M.G.; Carroll, K.K. Plasma cholesterol levels in rabbits fed low fat, cholesterol-free, semipurified diets: Effects of dietary proteins, protein hydrolysates and amino acid mixtures. Atherosclerosis 1977, 28, 187-195. [CrossRef]

17. Daley, S.J.; Herderick, E.E.; Cornhill, J.F.; Rogers, K.A. Cholesterol-fed and casein-fed rabbit models of atherosclerosis-Part 1: Differing lesion area and volume despite equal plasma cholesterol levels. Arterioscler. Thromb. 1994, 14, 95-104. [CrossRef]

18. Beynen, A.C.; Van der Meer, R.; West, C.E. Mechanism of casein-induced hypercholesterolemia: Primary and secondary features. Atherosclerosis 1986, 60, 291-293. [CrossRef]

19. Huff, M.W.; Carroll, K.K. Effects of dietary protein on turnover, oxidation, and absorption of cholesterol, and on steroid excretion in rabbits. J. Lipid Res. 1980, 21, 546-548.

20. Chao, Y.; Yamin, T.T.; Alberts, A.W. Effects of cholestyramine on low density lipoprotein binding sites on liver membranes from rabbits with endogenous hypercholesterolemia induced by a wheat starch-casein diet. J. Biol. Chem. 1982, 257, 3623-3627.

21. Watanabe, Y.; Ito, T.; Kondo, T. Breeding of a Rabbit Strain of Hyperlipidemia and Characteristic of These Strain. Exp. Anim. 1977, 26, 35-41. [CrossRef]

22. Watanabe, Y. Serial inbreeding of rabbits with hereditary hyperlipidemia (WHHL-rabbit). Incidence and development of atherosclerosis and xanthoma. Atherosclerosis 1980, 36, 261-268. [CrossRef]

23. Soutar, A.K.; Naoumova, R.P. Mechanisms of disease: Genetic causes of familial hypercholesterolemia. Nat. Clin. Pract. Cardiovasc. Med. 2007, 4, 214-225. [CrossRef] [PubMed]

24. Yamamoto, T.; Bishop, R.W.; Brown, M.S.; Goldstein, J.L.; Russell, D.W. Deletion in Cysteine-rich region of LDL receptor impedes transport to cell surface in WHHL rabbit. Science 1986, 232, 1230-1237. [CrossRef]

25. Kita, T.; Brown, M.S.; Watanabe, Y.; Goldstein, J.L. Deficiency of low density lipoprotein receptors in liver and adrenal gland of the WHHL rabbit, an animal model of familial hypercholesterolemia. Proc. Natl. Acad. Sci. USA 1981, 78, 2268-2272. [CrossRef]

26. Havel, R.J.; Kita, T.; Kotite, L.; Kane, J.P.; Hamilton, R.L.; Goldstein, J.L.; Brown, M.S. Concentration and composition of lipoproteins in blood plasma of the WHHL rabbit. An animal model of human familial hypercholesterolemia. Arteriosclerosis 1982, 2, 467-474. [CrossRef]

27. Goldstein, J.L.; Kita, T.; Brown, M.S. Defective Lipoprotein Receptors and Atherosclerosis: Lessons from an Animal Counterpart of Familial Hypercholesterolemia. N. Engl. J. Med. 1983, 309, 288-296. [CrossRef]

28. Shiomi, M.; Ito, T.; Fujioka, T.; Tsujita, Y. Age-associated decrease in plasma cholesterol and changes in cholesterol metabolism in homozygous Watanabe heritable hyperlipidemic rabbits. Metabolism 2000, 49, 552-556. [CrossRef]

29. Atkinson, J.B.; Hoover, R.L.; Berry, K.K.; Swift, L.L. Cholesterol-fed heterozygous Watanabe heritable hyperlipidemic rabbits: A new model for atherosclerosis. Atherosclerosis 1989, 78, 123-136. [CrossRef]

30. Zhang, B.; Saku, K.; Hirata, K.; Liu, R.; Tateishi, K.; Yamamoto, K.; Arakawa, K. Insulin resistance observed in WHHL rabbits. Atherosclerosis 1991, 91, 277-278. [CrossRef]

31. Shiomi, M.; Kobayashi, T.; Kuniyoshi, N.; Yamada, S.; Ito, T. Myocardial Infarction-Prone Watanabe Heritable Hyperlipidemic Rabbits with Mesenteric Fat Accumulation Are a Novel Animal Model for Metabolic Syndrome. Pathobiology 2012, 79, 329-338. [CrossRef] [PubMed]

32. Shiomi, M.; Ito, T.; Yamada, S.; Kawashima, S.; Fan, J. Development of an Animal Model for Spontaneous Myocardial Infarction (WHHLMI Rabbit). Arterioscler. Thromb. Vasc. Biol. 2003, 23, 1239-1244. [CrossRef] [PubMed] 
33. Shiomi, M.; Fan, J. Unstable coronary plaques and cardiac events in myocardial infarction-prone Watanabe heritable hyperlipidemic rabbits: Questions and quandaries. Curr. Opin. Lipidol. 2008, 19, 631-636. [CrossRef] [PubMed]

34. La Ville, A.; Turner, P.R.; Pittilo, R.M.; Martini, S.; Marenah, C.B.; Rowles, P.M.; Morris, G.; Thomson, G.A.; Woolf, N.; Lewis, B. Hereditary hyperlipidemia in the rabbit due to overproduction of lipoproteins. I. Biochemical studies. Arteriosclerosis 1987, 7, 105-112. [CrossRef]

35. Seddon, A.M.; Woolf, N.; La Ville, A.; Pittilo, R.M.; Rowles, P.M.; Turner, P.R.; Lewis, B. Hereditary hyperlipidemia and atherosclerosis in the rabbit due to overproduction of lipoproteins. II. Preliminary report of arterial pathology. Arteriosclerosis 1987, 7, 113-124. [CrossRef]

36. Ardern, H.A.; Benson, G.M.; Suckling, K.E.; Caslake, M.J.; Shepherd, J.; Packard, C.J. Apolipoprotein B overproduction by the perfused liver of the St. Thomas' mixed hyperlipidemic (SMHL) rabbit. J. Lipid Res. 1999, 40, 2234-2243.

37. de Roos, B.; Caslake, M.J.; Milliner, K.; Benson, G.M.; Suckling, K.E.; Packard, C.J. Characterisation of the lipoprotein structure in the St. Thomas' Mixed Hyperlipidaemic (SMHL) rabbit. Atherosclerosis 2005, 181, 63-68. [CrossRef]

38. Mitsuguchi, Y.; Ito, T.; Ohwada, K. Pathologic findings in rabbit models of hereditary hypertriglyceridemia and hereditary postprandial hypertriglyceridemia. Comp. Med. 2008, 58, 465-480.

39. Kawai, T.; Ito, T.; Ohwada, K.; Mera, Y.; Matsushita, M.; Tomoike, H. Hereditary postprandial hypertriglyceridemic rabbit exhibits insulin resistance and central obesity: A novel model of metabolic syndrome. Arterioscler. Thromb. Vasc. Biol. 2006, 26, 2752-2757. [CrossRef]

40. Fan, J.; McCormick, S.P.A.; Krauss, R.M.; Taylor, S.; Quan, R.; Taylor, J.M.; Young, S.G. Overexpression of Human Apolipoprotein B-100 in Transgenic Rabbits Results in Increased Levels of LDL and Decreased Levels of HDL. Arterioscler. Thromb. Vasc. Biol. 1995, 15, 1889-1899. [CrossRef]

41. Ding, Y.; Wang, Y.; Zhu, H.; Fan, J.; Yu, L.; Liu, G.; Liu, E. Hypertriglyceridemia and delayed clearance of fat load in transgenic rabbits expressing human apolipoprotein CIII. Transgenic Res. 2011, 20, 867-875. [CrossRef] [PubMed]

42. Fan, J.; Ji, Z.S.; Huang, Y.; de Silva, H.; Sanan, D.; Mahley, R.W.; Innerarity, T.L.; Taylor, J.M. Increased expression of apolipoprotein $\mathrm{E}$ in transgenic rabbits results in reduced levels of very low density lipoproteins and an accumulation of low density lipoproteins in plasma. J. Clin. Investig. 1998, 101, 2151-2164. [CrossRef] [PubMed]

43. Huang, Y.; Ji, Z.-S.; Brecht, W.J.; Rall, S.C.; Taylor, J.M.; Mahley, R.W. Overexpression of Apolipoprotein E3 in Transgenic Rabbits Causes Combined Hyperlipidemia by Stimulating Hepatic VLDL Production and Impairing VLDL Lipolysis. Arterioscler. Thromb. Vasc. Biol. 1999, 19, 2952-2959. [CrossRef] [PubMed]

44. Huang, Y.; Schwendner, S.W.; Rall, S.C.; Sanan, D.A.; Mahley, R.W. Apolipoprotein E2 Transgenic Rabbits. J. Biol. Chem. 1997, 272, 22685-22694. [CrossRef] [PubMed]

45. Yang, D.; Xu, J.; Zhu, T.; Fan, J.; Lai, L.; Zhang, J.; Chen, Y.E. Effective gene targeting in rabbits using RNA-guided Cas9 nucleases. J. Mol. Cell Biol. 2014, 6, 97-99. [CrossRef]

46. Ji, D.; Zhao, G.; Songstad, A.; Cui, X.; Weinstein, E.J. Efficient creation of an APOE knockout rabbit. Transgenic Res. 2015, 24, 227-235. [CrossRef]

47. Lu, R.; Yuan, T.; Wang, Y.; Zhang, T.; Yuan, Y.; Wu, D.; Zhou, M.; He, Z.; Lu, Y.; Chen, Y.; et al. Spontaneous severe hypercholesterolemia and atherosclerosis lesions in rabbits with deficiency of low-density lipoprotein receptor (LDLR) on exon 7. EBioMedicine 2018, 36, 29-38. [CrossRef]

48. Niimi, M.; Yang, D.; Kitajima, S.; Ning, B.; Wang, C.; Li, S.; Liu, E.; Zhang, J.; Chen, Y.E.; Fan, J. ApoE knockout rabbits: A novel model for the study of human hyperlipidemia. Atherosclerosis 2016, 245, 187-193. [CrossRef]

49. Yuan, T.; Zhong, Y.; Wang, Y.; Zhang, T.; Lu, R.; Zhou, M.; Lu, Y.; Yan, K.; Chen, Y.; Hu, Z.; et al. Generation of hyperlipidemic rabbit models using multiple sgRNAs targeted CRISPR/Cas9 gene editing system. Lipids Health Dis. 2019, 18, 69. [CrossRef]

50. Shiomi, M.; Koike, T.; Ito, T. Contribution of the WHHL rabbit, an animal model of familial hypercholesterolemia, to elucidation of the anti-atherosclerotic effects of statins. Atherosclerosis 2013, 231, 39-47. [CrossRef]

51. Endo, A.; Kuroda, M.; Tanzawa, K. Competitive inhibition of 3-hydroxy-3-methylglutaryl coenzyme a reductase by ML-236A and ML-236B fungal metabolites, having hypocholesterolemic activity. FEBS Lett. 1976, 72, 323-326. [CrossRef] 
52. Endo, A.; Tsujita, Y.; Kuroda, M.; Tanzawa, K. Effects of ML-236B on cholesterol metabolism in mice and rats: Lack of hypocholesterolemic activity in normal animals. Biochim. Biophys. Acta (BBA)/Lipids Lipid Metab. 1979, 575, 266-276. [CrossRef]

53. Endo, A. Regulation of cholesterol synthesis, as focused on the regulation of HMG-CoA reductase. Seikagaku 1980, 52, 1033-1049. [PubMed]

54. Watanabe, Y.; Ito, T.; Saeki, M.; Kuroda, M.; Tanzawa, K.; Mochizuki, M.; Tsujita, Y.; Arai, M. Hypolipidemic effects of CS-500 (ML-236B) in WHHL-rabbit, a heritable animal model for hyperlipidemia. Atherosclerosis 1981, 38, 27-31. [CrossRef]

55. Tsujita, Y.; Kuroda, M.; Tanzawa, K.; Kitano, N.; Endo, A. Hypolipidemic effects in dogs of ML-236B, a competitive inhibitor of 3-hydroxy-3-methylglutaryl coenzyme a reductase. Atherosclerosis 1979, 32, 307-313. [CrossRef]

56. Kuroda, M.; Tsujita, Y.; Tanzawa, K.; Endo, A. Hypolipidemic effects in monkeys of ML-236B, a competitive inhibitor of 3-hydroxy-3-methylglutaryl coenzyme A reductase. Lipids 1979, 14, 585-589. [CrossRef]

57. Knopp, R.H. Drug Treatment of Lipid Disorders. N. Engl. J. Med. 1999, 341, 498-511. [CrossRef]

58. Bocan, T.M.A.; Mazur, M.J.; Bak Mueller, S.; Brown, E.Q.; Sliskovic, D.R.; O’Brien, P.M.; Creswell, M.W.; Lee, H.; Uhlendorf, P.D.; Roth, B.D.; et al. Antiatherosclerotic activity of inhibitors of 3-hydroxy-3-methylglutaryl coenzyme A reductase in cholesterol-fed rabbits: A biochemical and morphological evaluation. Atherosclerosis 1994, 111, 127-142. [CrossRef]

59. Watanabe, Y.; Ito, T.; Masashi, S.; Tsujita, Y.; Kuroda, M.; Arai, M.; Fukamim, M.; Tamura, A. Preventive effect of pravastatin sodium, a potent inhibitor of 3-hydroxy-3-methylglutaryl coenzyme A reductase, on coronary atherosclerosis and xanthoma in WHHL rabbits. Biochim. Biophys. Acta (BBA)/Lipids Lipid Metab. 1988, 960, 294-302. [CrossRef]

60. Kroon, P.A.; Hand, K.M.; Huff, J.W.; Alberts, A.W. The effects of mevinolin on serum cholesterol levels of rabbits with endogenous hypercholesterolemia. Atherosclerosis 1982, 44, 41-48. [CrossRef]

61. Kritchevsky, D.; Tepper, S.A.; Klurfeld, D.M. Influence of mevinolin on experimental atherosclerosis in rabbits. Pharmacol. Res. Commun. 1981, 13, 921-926. [CrossRef]

62. Kobayashi, M.; Ishida, F.; Takahashi, T.; Taguchi, K.; Watanabe, K.; Ohmura, I.; Kamei, T. Preventive effect of MK-733 (simvastatin), an inhibitor of HMG-CoA reductase, on hypercholesterolemia and atherosclerosis induced by cholesterol feeding in rabbits. Jpn. J. Pharmacol. 1989, 49, 125-133. [CrossRef] [PubMed]

63. Auerbach, B.J.; Krause, B.R.; Bisgaier, C.L.; Newton, R.S. Comparative effects of HMG-CoA reductase inhibitors on apo B production in the casein-fed rabbit: Atorvastatin versus lovastatin. Atherosclerosis 1995, 115, 173-180. [CrossRef]

64. Rikitake, Y.; Kawashima, S.; Takeshita, S.; Yamashita, T.; Azumi, H.; Yasuhara, M.; Nishi, H.; Inoue, N.; Yokoyama, M. Anti-oxidative properties of fluvastatin, an HMG-CoA reductase inhibitor, contribute to prevention of atherosclerosis in cholesterol-fed rabbits. Atherosclerosis 2001, 154, 87-96. [CrossRef]

65. Hayashi, T.; Rani P, J.A.; Fukatsu, A.; Matsui-Hirai, H.; Osawa, M.; Miyazaki, A.; Tsunekawa, T.; Kano-Hayashi, H.; Iguchi, A.; Sumi, D.; et al. A new HMG-CoA reductase inhibitor, pitavastatin remarkably retards the progression of high cholesterol induced atherosclerosis in rabbits. Atherosclerosis 2004, 176, $255-263$. [CrossRef]

66. Ma, P.T.; Gil, G.; Südhof, T.C.; Bilheimer, D.W.; Goldstein, J.L.; Brown, M.S. Mevinolin, an inhibitor of cholesterol synthesis, induces mRNA for low density lipoprotein receptor in livers of hamsters and rabbits. Proc. Natl. Acad. Sci. USA 1986, 83, 8370-8374. [CrossRef]

67. Tsujita, Y.; Kuroda, M.; Shimada, Y.; Tanzawa, K.; Arai, M.; Kaneko, I.; Tanaka, M.; Masuda, H.; Tarumi, C.; Watanabe, Y.; et al. CS-514, a competitive inhibitor of 3-hydroxy-3-methylglutaryl coenzyme A reductase: Tissue-selective inhibition of sterol synthesis and hypolipidemic effect on various animal species. Biochim. Biophys. Acta (BBA)/Lipids Lipid Metab. 1986, 877, 50-60. [CrossRef]

68. Shiomi, M.; Ito, T. Effect of cerivastatin sodium, a new inhibitor of HMG-CoA reductase, on plasma lipid levels, progression of atherosclerosis, and the lesional composition in the plaques of WHHL rabbits. Br. J. Pharmacol. 1999, 126, 961-968. [CrossRef]

69. Suzuki, H.; Kobayashi, H.; Sato, F.; Yonemitsu, Y.; Nakashima, Y.; Sueishi, K. Plaque-stabilizing effect of pitavastatin in Watanabe heritable hyperlipidemic (WHHL) rabbits. J. Atheroscler. Thromb. 2003, 10, 109-116. [CrossRef] 
70. Staels, B.; Dallongeville, J.; Auwerx, J.; Schoonjans, K.; Leitersdorf, E.; Fruchart, J.-C. Mechanism of Action of Fibrates on Lipid and Lipoprotein Metabolism. Circulation 1998, 98, 2088-2093. [CrossRef]

71. Krause, B.R.; Princen, H.M.G. Lack of predictability of classical animal models for hypolipidemic activity: A good time for mice? Atherosclerosis 1998, 140, 15-24. [CrossRef]

72. Staels, B.; Auwerx, J. Regulation of apo A-I gene expression by fibrates. Atherosclerosis 1998, 137, S19-S23. [CrossRef]

73. Saitoh, K.; MoriI, T.; Kasai, H.; Nagayama, T.; Tsuchiya, A.; Ohbayashi, S. Anti-atheromatous effects of fenofibrate, a hypolipidemic drug. I. Anti-atheromatous effects are independent of its hypolipidemic effect in cholesterol-fed rabbits. Folia Pharmacol. Jpn. 1995, 106, 41-50. [CrossRef] [PubMed]

74. Corti, R.; Osende, J.; Hutter, R.; Viles-Gonzalez, J.F.; Zafar, U.; Valdivieso, C.; Mizsei, G.; Fallon, J.T.; Fuster, V.; Badimon, J.J. Fenofibrate induces plaque regression in hypercholesterolemic atherosclerotic rabbits: In vivo demonstration by high-resolution MRI. Atherosclerosis 2007, 190, 106-113. [CrossRef] [PubMed]

75. Jeanpierre, E.; Le Tourneau, T.; Zawadzki, C.; Van Belle, E.; Mouquet, F.; Susen, S.; Ezekowitz, M.D.; Staels, B.; Jude, B.; Corseaux, D. Beneficial effects of fenofibrate on plaque thrombogenicity and plaque stability in atherosclerotic rabbits. Cardiovasc. Pathol. 2009, 18, 140-147. [CrossRef] [PubMed]

76. Agarwala, A.; Kajani, Z.; Miedema, M.D.; Virani, S.S. The role of ezetimibe in the treatment of cardiovascular disease. Curr. Atheroscler. Rep. 2016, 18, 8. [CrossRef]

77. Gómez-Garre, D.; Muñoz-Pacheco, P.; González-Rubio, M.L.; Aragoncillo, P.; Granados, R.; Fernández-Cruz, A. Ezetimibe reduces plaque inflammation in a rabbit model of atherosclerosis and inhibits monocyte migration in addition to its lipid-lowering effect. Br. J. Pharmacol. 2009, 156, 1218-1227. [CrossRef]

78. Patel, R.; Janoudi, A.; Vedre, A.; Aziz, K.; Tamhane, U.; Rubinstein, J.; Abela, O.G.; Berger, K.; Abela, G.S. Plaque rupture and thrombosis are reduced by lowering cholesterol levels and crystallization with ezetimibe and are correlated with fluorodeoxyglucose positron emission tomography. Arterioscler. Thromb. Vasc. Biol. 2011, 31, 2007-2014. [CrossRef]

79. Honda, K.; Matoba, T.; Antoku, Y.; Koga, J.I.; Ichi, I.; Nakano, K.; Tsutsui, H.; Egashira, K. Lipid-Lowering Therapy with Ezetimibe Decreases Spontaneous Atherothrombotic Occlusions in a Rabbit Model of Plaque Erosion. Arterioscler. Thromb. Vasc. Biol. 2018, 38, 757-771. [CrossRef]

80. Ogawa, T.; Fujii, H.; Yoshizato, K.; Kawada, N. A human-type nonalcoholic steatohepatitis model with advanced fibrosis in rabbits. Am. J. Pathol. 2010, 177, 153-165. [CrossRef]

81. Barnhart, J.W.; Rytter, D.J.; Molello, J.A. An overview of the biochemical pharmacology of probucol. Lipids 1977, 12, 29-33. [CrossRef] [PubMed]

82. Yamashita, S.; Matsuzawa, Y. Where are we with probucol: A new life for an old drug? Atherosclerosis 2009, 207, 16-23. [CrossRef] [PubMed]

83. Naruszewicz, M.; Carew, T.E.; Pittman, R.C.; Witztum, J.L.; Steinberg, D. A novel mechanism by which probucol lowers low density lipoprotein levels demonstrated in the LDL receptor-deficient rabbit. J. Lipid Res. 1984, 25, 1206-1213. [PubMed]

84. Kita, T.; Nagano, Y.; Yokode, M.; Ishii, K.; Kume, N.; Ooshima, A.; Yoshida, H.; Kawai, C. Probucol prevents the progression of atherosclerosis in Watanabe heritable hyperlipidemic rabbit, an animal model for familial hypercholesterolemia. Proc. Natl. Acad. Sci. USA 1987, 84, 5928-5931. [CrossRef]

85. Carew, T.E.; Schwenke, D.C.; Steinberg, D. Antiatherogenic effect of probucol unrelated to its hypocholesterolemic effect. Proc. Natl. Acad. Sci. USA 1987, 84, 7725-7729. [CrossRef]

86. Daugherty, A.; Zweifel, B.S.; Schonfeld, G. Probucol attenuates the development of aortic atherosclerosis in cholesterol-fed rabbits. Br. J. Pharmacol. 1989, 98, 612-618. [CrossRef]

87. Oshima, R.; Ikeda, T.; Watanabe, K.; Itakura, H.; Sugiyama, N. Probucol treatment attenuates the aortic atherosclerosis in Watanabe heritable hyperlipidemic rabbits. Atherosclerosis 1998, 137, 13-22. [CrossRef]

88. Daugherty, A.; Zweifel, B.S.; Schonfeld, G. The effects of probucol on the progression of atherosclerosis in mature Watanabe heritable hyperlipidaemic rabbits. Br. J. Pharmacol. 1991, 103, 1013-1018. [CrossRef]

89. Niimi, M.; Keyamura, Y.; Nozako, M.; Koyama, T.; Kohashi, M.; Yasufuku, R.; Yoshikawa, T.; Fan, J. Probucol inhibits the initiation of atherosclerosis in cholesterol-fed rabbits. Lipids Health Dis. 2013, 12, 166. [CrossRef]

90. Li, S.; Liang, J.; Niimi, M.; Waqar, A.B.; Kang, D.; Koike, T.; Wang, Y.; Shiomi, M.; Fan, J. Probucol suppresses macrophage infiltration and MMP expression in atherosclerotic plaques of WHHL rabbits. J. Atheroscler. Thromb. 2014, 21, 648-658. [CrossRef] 
91. Steinberg, D. The LDL modification hypothesis of atherogenesis: An update. J. Lipid Res. 2009, 50, S376-S381. [CrossRef] [PubMed]

92. Gordon, T.; Castelli, W.P.; Hjortland, M.C.; Kannel, W.B.; Dawber, T.R. High density lipoprotein as a protective factor against coronary heart disease: The Framingham study. Am. J. Med. 1977, 62, 707-714. [CrossRef]

93. Chapman, M.J.; Le Goff, W.; Guerin, M.; Kontush, A. Cholesteryl ester transfer protein: At the heart of the action of lipid-modulating therapy with statins, fibrates, niacin, and cholesteryl ester transfer protein inhibitors. Eur. Heart J. 2010, 31, 149-164. [CrossRef] [PubMed]

94. Kobayashi, J.; Okamoto, H.; Otabe, M.; Bujo, H.; Saito, Y. Effect of HDL, from Japanese white rabbit administered a new cholesteryl ester transfer protein inhibitor JTT-705, on cholesteryl ester accumulation induced by acetylated low density lipoprotein in J774 macrophage. Atherosclerosis 2002, 162, 131-135. [CrossRef]

95. Brodeur, M.R.; Rhainds, D.; Charpentier, D.; Mihalache-Avram, T.; Mecteau, M.; Brand, G.; Chaput, E.; Perez, A.; Niesor, E.J.; Rhéaume, E.; et al. Dalcetrapib and anacetrapib differently impact HDL structure and function in rabbits and monkeys. J. Lipid Res. 2017, 58, 1282-1291. [CrossRef] [PubMed]

96. Okamoto, H.; Yonemori, F.; Wakitani, K.; Minowa, T.; Maeda, K.; Shinkai, H. A cholesteryl ester transfer protein inhibitor attenuate atherosclerosis in rabbits. Nature 2000, 406, 203-207. [CrossRef] [PubMed]

97. Huang, Z.; Inazu, A.; Nohara, A.; Higashikata, T.; Mabuchi, H. Cholesteryl ester transfer protein inhibitor (JTT-705) and the development of atherosclerosis in rabbits with severe hypercholesterolaemia. Clin. Sci. 2002, 103, 587-594. [CrossRef]

98. Morehouse, L.A.; Sugarman, E.D.; Bourassa, P.A.; Sand, T.M.; Zimetti, F.; Gao, F.; Rothblat, G.H.; Milici, A.J. Inhibition of CETP activity by torcetrapib reduces susceptibility to diet-induced atherosclerosis in New Zealand White rabbits. J. Lipid Res. 2007, 48, 1263-1272. [CrossRef]

99. Miyosawa, K.; Watanabe, Y.; Murakami, K.; Murakami, T.; Shibata, H.; Iwashita, M.; Yamazaki, H.; Yamazaki, K.; Ohgiya, T.; Shibuya, K.; et al. New CETP inhibitor K-312 reduces PCSK9 expression: A potential effect on LDL cholesterol metabolism. Am. J. Physiol. Endocrinol. Metab. 2015, 309, E177-E190. [CrossRef]

100. Zhang, J.; Niimi, M.; Yang, D.; Liang, J.; Xu, J.; Kimura, T.; Mathew, A.V.; Guo, Y.; Fan, Y.; Zhu, T.; et al. Deficiency of Cholesteryl Ester Transfer Protein Protects Against Atherosclerosis in Rabbits. Arterioscler. Thromb. Vasc. Biol. 2017, 37, 1068-1075. [CrossRef]

101. Tall, A.R.; Rader, D.J. Trials and Tribulations of CETP Inhibitors. Circ. Res. 2018, 122, 106-112. [CrossRef] [PubMed]

102. Rosenson, R.S.; Brewer, H.B.; Ansell, B.; Barter, P.; Chapman, M.J.; Heinecke, J.W.; Kontush, A.; Tall, A.R.; Webb, N.R. Translation of high-density lipoprotein function into clinical practice: Current prospects and future challenges. Circulation 2013, 128, 1256-1267. [CrossRef] [PubMed]

103. Riwanto, M.; Landmesser, U. High density lipoproteins and endothelial functions: Mechanistic insights and alterations in cardiovascular disease. J. Lipid Res. 2013, 54, 3227-3243. [CrossRef] [PubMed]

104. Rosenson, R.S.; Brewer, H.B.; Davidson, W.S.; Fayad, Z.A.; Fuster, V.; Goldstein, J.; Hellerstein, M.; Jiang, X.C.; Phillips, M.C.; Rader, D.J.; et al. Cholesterol efflux and atheroprotection: Advancing the concept of reverse cholesterol transport. Circulation 2012, 125, 1905-1919. [CrossRef]

105. Badimon, J.; Badimon, L.; Galvez, A.; Dische, R.; Fuster, V. High density lipoprotein plasma fractions inhibit aortic fatty streaks in cholesterol-fed rabbits. Lab. Investig. 1989, 60, 455-461.

106. Badimon, J.J.; Badimon, L.; Fuster, V. Regression of atherosclerotic lesions by high density lipoprotein plasma fraction in the cholesterol-fed rabbit. J. Clin. Investig. 1990, 85, 1234-1241. [CrossRef]

107. Ben-Aicha, S.; Casaní, L.; Muñoz-García, N.; Joan-Babot, O.; Peña, E.; Aržanauskaitè, M.; Gutierrez, M.; Mendieta, G.; Padró, T.; Badimon, L.; et al. HDL (High-Density Lipoprotein) Remodeling and Magnetic Resonance Imaging-Assessed Atherosclerotic Plaque Burden: Study in a Preclinical Experimental Model. Arterioscler. Thromb. Vasc. Biol. 2020, 40, 2481-2493. [CrossRef]

108. Miyazaki, A.; Sakuma, S.; Morikawa, W.; Takiue, T.; Miake, F.; Terano, T.; Sakai, M.; Hakamata, H.; Sakamoto, Y.I.; Naito, M.; et al. Intravenous injection of rabbit apolipoprotein A-I inhibits the progression of atherosclerosis in cholesterol-fed rabbits. Arterioscler. Thromb. Vasc. Biol. 1995, 15, 1882-1888. [CrossRef]

109. Soma, M.R.; Donetti, E.; Parolini, C.; Sirtori, C.R.; Fumagalli, R.; Franceschini, G. Recombinant apolipoprotein A-IMilano dimer inhibits carotid intimai thickening induced by perivascular manipulation in rabbits. Circ. Res. 1995, 76, 405-411. [CrossRef] 
110. Chiesa, G.; Monteggia, E.; Marchesi, M.; Lorenzon, P.; Laucello, M.; Lorusso, V.; Di Mario, C.; Karvouni, E.; Newton, R.S.; Bisgaier, C.L.; et al. Recombinant apolipoprotein A-IMilano infusion into rabbit carotid artery rapidly removes lipid from fatty streaks. Circ. Res. 2002, 90, 974-980. [CrossRef]

111. Ibanez, B.; Vilahur, G.; Cimmino, G.; Speidl, W.S.; Pinero, A.; Choi, B.G.; Zafar, M.U.; Santos-Gallego, C.G.; Krause, B.; Badimon, L.; et al. Rapid Change in Plaque Size, Composition, and Molecular Footprint After Recombinant Apolipoprotein A-IMilano (ETC-216) Administration. Magnetic Resonance Imaging Study in an Experimental Model of Atherosclerosis. J. Am. Coll. Cardiol. 2008, 51, 1104-1109. [CrossRef] [PubMed]

112. Duverger, N.; Kruth, H.; Emmanuel, F.; Caillaud, J.-M.; Viglietta, C.; Castro, G.; Tailleux, A.; Fievet, C.; Fruchart, J.C.; Houdebine, L.M.; et al. Inhibition of Atherosclerosis Development in Cholesterol-Fed Human Apolipoprotein A-I-Transgenic Rabbits. Circulation 1996, 94, 713-717. [CrossRef] [PubMed]

113. Wang, Y.; Niimi, M.; Nishijima, K.; Waqar, A.B.; Yu, Y.; Koike, T.; Kitajima, S.; Liu, E.; Inoue, T.; Kohashi, M.; et al. Human apolipoprotein A-II protects against diet-induced atherosclerosis in transgenic rabbits. Arterioscler. Thromb. Vasc. Biol. 2013, 33, 224-231. [CrossRef] [PubMed]

114. Anantharamaiah, G.; Jones, J.; Brouillette, C.; Schmidt, C.; Chung, B.; Hughes, T.; Bhown, A.; Segrest, J. Studies of synthetic peptide analogs of the amphipathic helix. Structure of complexes with dimyristoyl phosphatidylcholine. J. Biol. Chem. 1985, 260, 10248-10255.

115. White, C.R.; Datta, G.; Zhang, Z.; Gupta, H.; Garber, D.W.; Mishra, V.K.; Palgunachari, M.N.; Handattu, S.P.; Chaddha, M.; Anantharamaiah, G.M. HDL therapy for cardiovascular diseases: The road to HDL mimetics. Curr. Atheroscler. Rep. 2008, 10, 405-412. [CrossRef] [PubMed]

116. Gupta, H.; White, C.R.; Handattu, S.; Garber, D.W.; Datta, G.; Chaddha, M.; Dai, L.; Gianturco, S.H.; Bradley, W.A.; Anantharamaiah, G.M. Apolipoprotein E mimetic peptide dramatically lowers plasma cholesterol and restores endothelial function in Watanabe heritable hyperlipidemic rabbits. Circulation 2005, 111, 3112-3118. [CrossRef]

117. Van Lenten, B.J.; Wagner, A.C.; Navab, M.; Anantharamaiah, G.M.; Hama, S.; Reddy, S.T.; Fogelman, A.M. Lipoprotein inflammatory properties and serum amyloid A levels but not cholesterol levels predict lesion area in cholesterol-fed rabbits. J. Lipid Res. 2007, 48, 2344-2353. [CrossRef]

118. Iwata, A.; Miura, S.I.; Zhang, B.; Imaizumi, S.; Uehara, Y.; Shiomi, M.; Saku, K. Antiatherogenic effects of newly developed apolipoprotein A-I mimetic peptide/phospholipid complexes against aortic plaque burden in Watanabe-heritable hyperlipidemic rabbits. Atherosclerosis 2011, 218, 300-307. [CrossRef]

119. Overturf, M.L.; Smith, S.A.; Hewett-Emmett, D.; Loose-Mitchell, D.S.; Soma, M.R.; Gotto, A.M., Jr.; Morrisett, J.D. Development and partial metabolic characterization of a dietary cholesterol-resistant colony of rabbits. J. Lipid Res. 1989, 30, 263-273.

120. Beynen, A.C.; Meijer, G.W.; Lemmens, A.G.; Glatz, J.F.C.; Versluis, A.; Katan, M.B.; Van Zutphen, L.F.M. Sterol balance and cholesterol absorption in inbred strains of rabbits hypo- or hyperresponsive to dietary cholesterol. Atherosclerosis 1989, 77, 151-157. [CrossRef]

121. Chen, Y.; Zhao, S.; Huang, B.; Wang, Y.; Li, Y.; Waqar, A.B.; Liu, R.; Bai, L.; Fan, J.; Liu, E. Probucol and cilostazol exert a combinatorial anti-atherogenic effect in cholesterol-fed rabbits. Thromb. Res. 2013, 132, 565-571. [CrossRef] [PubMed]

122. Clay, M.A.; Hopkins, G.J.; Ehnholm, C.P.; Barter, P.J. The rabbit as an animal model of hepatic lipase deficiency. Biochim. Biophys. Acta (BBA)/Lipids Lipid Metab. 1989, 1002, 173-181. [CrossRef]

123. Warren, R.J.; Ebert, D.L.; Mitchell, A.; Barter, P.J. Rabbit hepatic lipase cDNA sequence: Low activity is associated with low messenger RNA levels. J. Lipid Res. 1991, 32, 1333-1339. [PubMed]

124. Kimura, N.; Kikumori, A.; Kawase, D.; Okano, M.; Fukamachi, K.; Ishida, T.; Nakajima, K.; Shiomi, M. Species differences in lipoprotein lipase and hepatic lipase activities: Comparative studies of animal models of lifestyle-related diseases. Exp. Anim. 2019, 68, 267-275. [CrossRef] [PubMed]

Publisher's Note: MDPI stays neutral with regard to jurisdictional claims in published maps and institutional affiliations. 